A Journal of Agricultural Science Publisbed by the California Agricultural Experiment Station

CONTENTS

\title{
SOD WEBWORMS \\ AND OTHER LAWN PESTS IN CALIFORNIA
}

RICHARD M. BOHART 


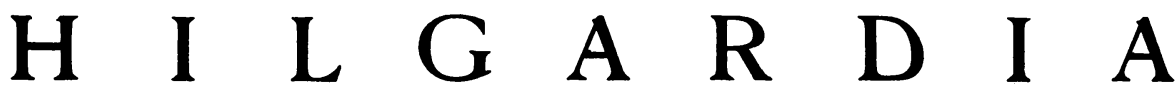

A Journal of Agricultural Science Published by

the California Agricultural Experiment Station

\section{SOD WEBWORMS AND OTHER LAWN PESTS IN CALIFORNIA}

\author{
RICHARD M. BOHART²
}

\section{INTRODUCTION}

AFTER the summer of 1929 , various publications began to record widespread damage to lawns and golf courses by certain species of the pyralid genus Crambus. In 1931, outbreaks of unprecedented magnitude occurred in many states, and the sod webworms, more popularly known as lawn moths, became recognized as major lawn pests.

In California, sod webworms have been reported as causing more or less severe injury every year since 1929. The damage to private lawns, parks, and golf greens cannot well be evaluated in money. Undoubtedly, hundreds of thousands of dollars have been expended in this state in controlling this pest and replacing the injured grass.

Lacking accurate information on lawn insects in California, pest-control operators have failed to agree on control practices. The author, accordingly, studied the subject from the fall of 1938 through 1941 in order to summarize the existing knowledge of such pests, present new biological data, and suggest practical means of control.

\section{ECONOMIC HISTORY OF SOD WEBWORMS}

The genus Crambus is practically world-wide in distribution and many of its species are recognized as agricultural pests. Crambus species have injured lawns and rice in Mauritius, pasture in Norway and England, sugar cane in Queensland, and rice in Brazil. In North America about 100 species are known, and some had attacked corn, oats, wheat, and pasture land as early as 1850. By 1895 the cranberry girdler, $C$. hortuellus (Hbn.) was a problem along the Atlantic seaboard. A few years later the corn root webworm, C. caliginosellus Clem. became a prominent pest of tobacco. Although Felt $(1894)^{3}$ pointed out that the members of the genus Crambus are predominantly grass feeders, their injury to pasture received only an occasional comment till the publication of G. G. Ainslee's studies beginning in 1917.

\footnotetext{
${ }^{1}$ Received for publication March 17, 1943.

${ }^{2}$ Assistant Professor of Entomology and Assistant Entomologist in the Experiment Station.

see "Literature Cited" for complete data on citations mentioned in the text by author and date of publication.
} 
Damage by webworms to lawns or golf courses was recorded only twice, apparently, before 1929. Moznette (1921) reported injury to Florida turf by Crambus haytiellus Zinck. Ainslee (1922a) mentioned sod webworms as occasional pests of lawn grass, "especially in times of deficient rainfall." In the summer of 1929, however, and in the following four summers, damage to lawn grass by species of Crambus was widespread in North America. Outbreaks during these years apparently coincided with the drought that prevailed over much of the country. Noble (1932) suggested that the injury to lawns and golf greens from the excessive numbers of sod webworms in 1931 "was due to their gradual concentration in artificially watered areas of grass during the dry summers of 1930 and 1931 and to the unusually large numbers of the overwintering forms which survived the mild weather of the preceding winters."

The first published report of sod-webworm damage to California lawns (Brock, 1929) also coincided with the beginning of a series of relatively dry years. Between 1928 and 1934, although California did not participate so fully in the general drought as some other sections, there was much less rain here than usual. According to U.S. Weather Bureau reports the average annual rainfall deficit from July, 1928, to June, 1934, was 32.1 per cent in Sacramento, 22.5 per cent in San Francisco, 26.0 per cent in Fresno, and 9.0 per cent in Los Angeles. Since lawns and golf courses are always irrigated, the moths may congregate in these areas in dry years. Brock (1929) reported that during the summer of 1929 bent-grass and bluegrass lawns were injured in Orange County. Both Crambus bonifatellus and C. sperryellus (misidentified as $C$. cypeidalis) were present. Keifer (1931) noted $C$. sperryellus (misidentified as C. leachellus) as damaging lawns in San Joaquin County "during the latter part of summer and early fall" of 1931. Although published records are not available for 1931 to 1938 in California, sod webworms took a yearly toll of lawns and golf courses in many sections, according to greenkeepers and pest-control operators interviewed during the present study. In the summer of 1939, extensive injury in southern California was observed by the writer. Unofficial estimates by county authorities handling complaints from homeowners placed the damage in Los Angeles County alone at more than $\$ 75,000$. After the heavy rainfalls of 1939-40 and 1940-41, infestations were less severe. Although injury during the summer of 1941 was reported throughout the Sacramento and San Joaquin valleys and in the coastal district from Santa Rosa south to San Diego, outbreaks were apparently only local.

\section{GEOGRAPHICAL DISTRIBUTION}

Crambus bonifatellus.-Hulst (1887) originally described Crambus bonifatellus from Colorado. Dyar (1904) recorded it from Ainsworth, Bear Lake, and Revelstoke in British Columbia. According to A. B. Klots, an authority on Crambus, $C$. bonifatellus appears to occur throughout the Canadian Zone of the entire Rocky Mountain and Great Basin area. Out-of-state specimens in the writer's collection are from Hubbard, Forest Grove, and Corvallis, Oregon. Keifer (1931) first recorded this species in California. The known distribu-

\footnotetext{
${ }^{4}$ Personal correspondence.
} 
tion here is indicated in figure $1, B$. In general it occurs in a narrow coastal belt no more than 50 miles wide. Exceptional localities are Sacramento, Oroville, Goodyear Bar, and Lake Tahoe. The Sacramento and Oroville specimens were collected by $\mathrm{H}$. H. Keifer, who told the writer that the species was extremely rare in these localities. All inland records are recent (1926 to 1941), and the specimens have been associated with lawns. Collections along the coast were noted as early as 1908 (San Francisco) and 1913 (San Diego, W. S. Wright), but without host designation.

Crambus sperryellus.-Crambus sperryellus is apparently restricted mainly to California. Here, however, it is more widely distributed than C. bonifatellus.

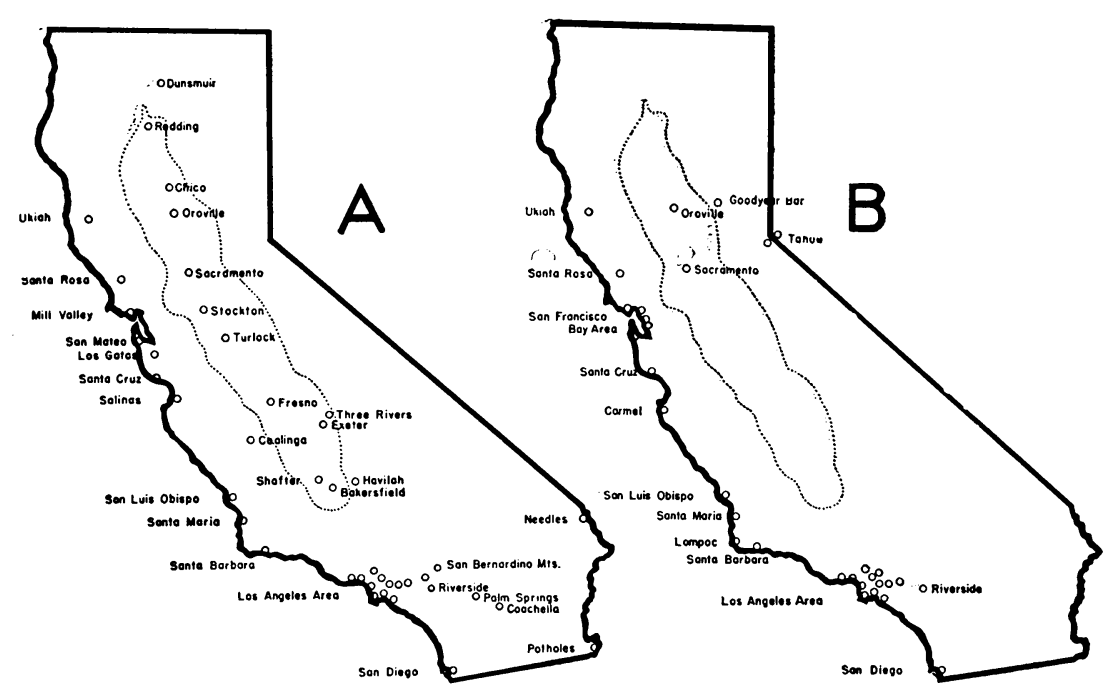

Fig. 1.-Distribution map of California lawn moths: $A$, Crambus sperryellus; $B$, Crambus bonifatellus. The dotted lines indicate the approximate boundary of the Sacramento and San Joaquin valleys.

Klots (1940) records it from Dunsmuir, Sacramento, Santa Cruz, Three Rivers, Exeter, Havilah, Saugus, the Los Angeles area, Claremont, the San Bernardino Mountains (6,000 feet), Colton, Riverside, Palm Springs, Coachella, Needles, and San Diego, as well as Tempe, Arizona. The writer has seen specimens from Grants Pass, Oregon, and from the additional California localities marked on the map, figure 1, $A$. The species abounds in the Sacramento and San Joaquin valleys as well as near the ocean. On the coast and in southern California as far inland as Riverside, both species may fly together; but, as a rule, one or the other will predominate on a given lawn or golf course.

\section{HOST-RANGE STUDIES}

Lawns in California are usually of Bermuda grass, orchard grass, Kentucky bluegrass, Australian ryegrass (Lolium spp.), or creeping bent. Bent and bluegrass are generally conceded to make the finest turf. Australian ryegrass is relatively inexpensive, but individual plants tend to segregate, so that the 
ground cover may not be smooth. In some districts ryegrass grows so poorly, especially from cheap seed, that the sparse appearance is frequently mistaken for lawn-moth damage. Bermuda grass and orchard grass ordinarily appear first as weeds, but once established will make serviceable lawns.

Field Observations on Host Preferences.-In the writer's experience only bent-grass and young bluegrass lawns have been injured by sod webworms. Although young Bermuda grass lawns have occasionally been reported as

TABLE 1

Laboratory Host-Range Studies on Crambus bonifatellus AND Crambus sperryellus*

\begin{tabular}{|c|c|c|c|c|}
\hline \multirow[b]{2}{*}{ Host plant } & \multicolumn{2}{|c|}{ Crambus bonifatellus } & \multicolumn{2}{|c|}{ Crambus sperryellus } \\
\hline & $\begin{array}{l}\text { Instar } \\
\text { attained }\end{array}$ & $\begin{array}{c}\text { Average } \\
\text { time from } \\
\text { eclosion to } \\
\text { pupation }\end{array}$ & $\begin{array}{l}\text { Instar } \\
\text { attained }\end{array}$ & $\begin{array}{l}\text { Average } \\
\text { time from } \\
\text { eclosion to } \\
\text { pupation }\end{array}$ \\
\hline White clover (Trifolium repens). & 6 & $\begin{array}{l}\text { days } \\
23.0\end{array}$ & 8 & $\begin{array}{l}\text { days } \\
39.5\end{array}$ \\
\hline Orchard grass (Dactylis glomerata) $\ldots \ldots \ldots \ldots \ldots \ldots \ldots$ & 7 & 26.0 & $7 \dagger$ & ... \\
\hline 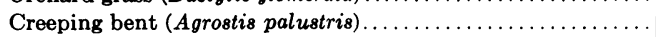 & 6 & 27.0 & $6 \dagger$ & $\cdots$ \\
\hline 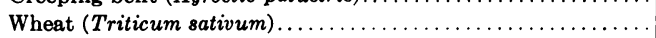 & 6 & 27.0 & $8 \dagger$ & $\cdots$ \\
\hline Kentucky bluegrass (Poa pratensis). & 6 & 29.0 & 8 & 34.5 \\
\hline Australian ryegrass (Lolium spp.)... & 7 & 31.5 & 7 & 34.0 \\
\hline Bermuda grass (Cynodon dactylon) $\ldots \ldots \ldots \ldots \ldots \ldots \ldots$ & 7 & 34.0 & 7 & 31.0 \\
\hline Crabgrass (Digitaria sanguinalis) $\ldots \ldots \ldots \ldots \ldots \ldots \ldots \ldots$ & 8 & 37.0 & $9 \dagger$ & $\ldots$ \\
\hline Rescue grass (Bromus catharticus) ............... & $7 \dagger$ & $\ldots$ & 8 & 40.5 \\
\hline 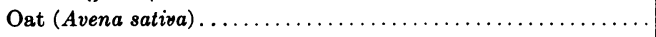 & $7 \dagger$ & $\ldots$ & $7 \dagger$ & $\ldots$ \\
\hline Corn $($ Zea mays $) \ldots \ldots \ldots \ldots \ldots \ldots$ & $5 \dagger$ & $\ldots$ & 7 & 42.0 \\
\hline Ripgut grass (Bromus rigidus) $\ldots \ldots \ldots \ldots \ldots \ldots \ldots \ldots \ldots$ & $1 \dagger$ & $\ldots$ & $6 \dagger$ & $\ldots$ \\
\hline Pampas grass (Cortaderia selloana) ............... & $1 \dagger$ & $\ldots$ & $1 \dagger$ & $\ldots$ \\
\hline Barley (Hordeum vulgare) ................ & $1 \dagger$ & $\ldots$ & $1 \dagger$ & $\ldots$ \\
\hline St. Augustine grass (Stenotaphrum secundatum)............ & $1 \dagger$ & $\ldots$ & $1 \dagger$ & $\ldots$ \\
\hline Barnyard grass (Echinochloa crus-galli) .................. & $1 \dagger$ & $\ldots$ & 7 & 34.0 \\
\hline Dichondra (Dichondra repens) ....................... & $1 \dagger$ & $\ldots$ & $1 \dagger$ & $\ldots$ \\
\hline
\end{tabular}

* In each test 15 newly hatched larvae were used. Room temperatures of $73^{\circ}$ to $77^{\circ} \mathrm{F}$ prevailed through the experiment.

$\dagger$ All specimens on this plant species died before pupation.

attacked, he has seen no instances personally. An attempt was made to determine whether the apparent immunity of Bermuda grass, orchard grass, and ryegrass resulted from a paucity of sod-webworm larvae or from a greater resistance of the grass. Whenever control experiments were conducted on bent or bluegrass, adjacent lawns were searched for the larvae with a pyrethrum testing solution. ${ }^{5}$ Apparently Bermuda grass and Australian ryegrass lawns seldom harbored more than 2 or 3 Crambus larvae to the square yard even when they adjoined severely infested bent or bluegrass lawns. On the other hand, orchard grass sometimes had a high population without showing injury. Though the leaves are tender, the individual plants are very large as compared with bluegrass, and size may account for the greater resistance. Bluegrass lawns a year old or older were ordinarily not injured perceptibly even in the worst-infested districts. As a rule, such plots contained only about 25 larvae

5 The testing solution was prepared from a commercial water-miscible extract containing about 2 per cent pyrethrins, diluted 1 part to 400 parts of water (equivalent to about 2 teaspoons of extract to a gallon of water). The mixture was applied to grass with a sprinkling can, 1 quart to $1 / 4$ square yard. 
or fewer to the square yard, though in one case an average of 104 were causing no apparent damage. The resistance of old lawns can be attributed to the better establishment of the plants and to a greater toughness, which makes the bluegrass less suitable as larval food.

Laboratory Studies on Host Range.-In the search for more definite information on the host range of the two California species of lawn-infesting Crambus, specimens were reared in the laboratory on cut leaves of various grasses and other plants-sweet corn, orchard grass, ripgut grass, rescue grass, Kentucky bluegrass, pampas grass, Australian ryegrass, wheat, barley, Bermuda grass, oat, creeping bent, St. Augustine grass, crabgrass, barnyard grass, white clover, and Dichondra repens. Table 1 presents the results.

TABLE 2

I aboratory Tests on Larval Food Preferences

\begin{tabular}{|c|c|c|c|c|c|c|}
\hline \multirow{3}{*}{ Host plant } & \multicolumn{6}{|c|}{ Number of larvae feeding on a given host* } \\
\hline & \multicolumn{3}{|c|}{ Crambus bonifatellus } & \multicolumn{3}{|c|}{ Crambus sperryellus } \\
\hline & Test 1 & Test 2 & Test 3 & Test 4 & Test 5 & Test 6 \\
\hline Kentucky bluerrass & larvae & larvae & larvae & $\begin{array}{c}\text { larvae } \\
14\end{array}$ & larvae & larvae \\
\hline White clover......... & 10 & $\begin{array}{l}20 \\
. .\end{array}$ & $\ddot{22}$ & $\begin{array}{r}17 \\
6\end{array}$ & .. & $\ddot{9}$ \\
\hline Orchard grass............. & 4 & . & . & 10 & . & . \\
\hline Australian ryegrass $\ldots \ldots \ldots \ldots \ldots \ldots \ldots \ldots$ & . & 4 & 6 & . & 6 & 18 \\
\hline 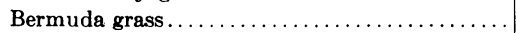 & . & 1 & 2 & . & 3 & 3 \\
\hline
\end{tabular}

* Thirty larvae were used in each test.

Neither species of moth could be reared beyond the first instar on pampas grass, barley, St. Augustine grass, or Dichondra repens, nor could Crambus bonifatellus live on barnyard grass or ripgut grass. C. sperryellus was apparently better able to use coarser food such as ripgut grass, Bermuda grass, and barnyard grass. The inability of $C$. sperryellus to complete development on creeping bent does not agree, however, with its behavior in lawns, where this grass is the type most susceptible to infestation.

These experiments, in which larvae were offered only one type of food, present a clearer picture of host potentialities than of food preferences. Further tests, accordingly, were made to determine the result of offering larvae a choice among five common lawn plants (table 2). For Crambus bonifatellus the order of preference was Kentucky bluegrass, white clover, orchard grass, Australian ryegrass, and Bermuda grass ; and for $C$. sperryellus the order was the same except that clover was fourth on the list. The relative distaste shown by both species for Australian ryegrass and Bermuda grass agreed with field observations, but the apparent fondness of $C$. bonifatellus for clover was surprising, since no injury to this plant has been reported.

\section{DIAGNOSIS OF SOD-WEBWORM INFESTATION}

Lawn grasses are susceptible to many entomological, pathological, and physiological ills. These troubles are often confused and incorrectly treated, with resultant loss of time and money. The usual restriction of lawn moths to 
bent-grass lawns or to bluegrass lawns not over a year old, somewhat simplifies the problem.

To identify lawn-moth damage, the writer used the following criteria: (1) Irregular brown patches were usually present instead of the circular spots associated with fungus. (2) On close examination the grass near the dead areas evidenced larval feeding by its shortness or uneven height. (3) Numerous adult moths were present, resting in the shrubbery or under window ledges near the lawn. (4) Predatory yellowjackets or parasitic wasps and flies, if abundant, pointed to a high population of host larvae. (5) Green areas near damaged sections of the lawn were tested with a pyrethrum solution (footnote 5 , p. 270). This fifth criterion was by far the most reliable : if at least 100 sodwebworm larvae to the square yard wriggled to the surface within 10 minutes, a serious infestation was indicated.

Three rather unsatisfactory methods of diagnosis were sectioning, flooding, and the use of hot water. In the first, a section of sod was removed with a knife, and the grass was torn apart. The task was not easy, however, unless the larval population was extremely high; often the small specimen of sod that could feasibly be examined gave an erroneous idea of the infestation. In the second method a suspected section of lawn was flooded with a hose for 15 minutes or more to drive the larvae to the surface. This procedure, however, was inefficient. When very hot water was poured on, the larvae wriggled to the surface: but such treatment damaged the grass.

Two phenomena that were not reliable, being often associated with relatively healthy lawns, were the presence of adult lawn moths at dusk, and the visitations of blackbirds in flocks during the day.

\section{TAXONOMY}

Although Crambus moths and related genera are sometimes separated in a special family, Crambidae, recent workers treat them as the subfamily Crambinae of the family Pyralidae. The species of Crambus fold their wings in repose closely about the body, and have prominent porrect labial palpi. Of the eighteen species reported from California, only two, C. bonifatellus (Hulst) and C. sperryellus Klots, are known to infest lawns. Their systematic history is as follows :

Crambus bonifatellus (Hulst)

Spermatophthora (q) bonifatella Hulst, 1887, Ent. Amer. 3:135.

Crambus bonifatellus Fernald, 1896, Massachusetts Agr. Col. Spec. Bul. p. 57.

Apparently Crambus bonifatellus has no close relatives. The brownish forewing variegated with buff, whitish, and black distinguishes it from all other North American species (fig. 2, $A$ and $B$ ).

\section{Crambus sperryellus Klots}

Crambus cypridalis of Brock, 1929. California State Dept. Agr. Monthly Bul. 18:574 (based on misidentification).

Crambus leachellus of Keifer, 1931. California Dept. Agr. Monthly Bul. 20:617 (based on misidentification).

Crambus sperryellus Klots, 1940. Southern California Acad. Sci. Bul. 39:62. 

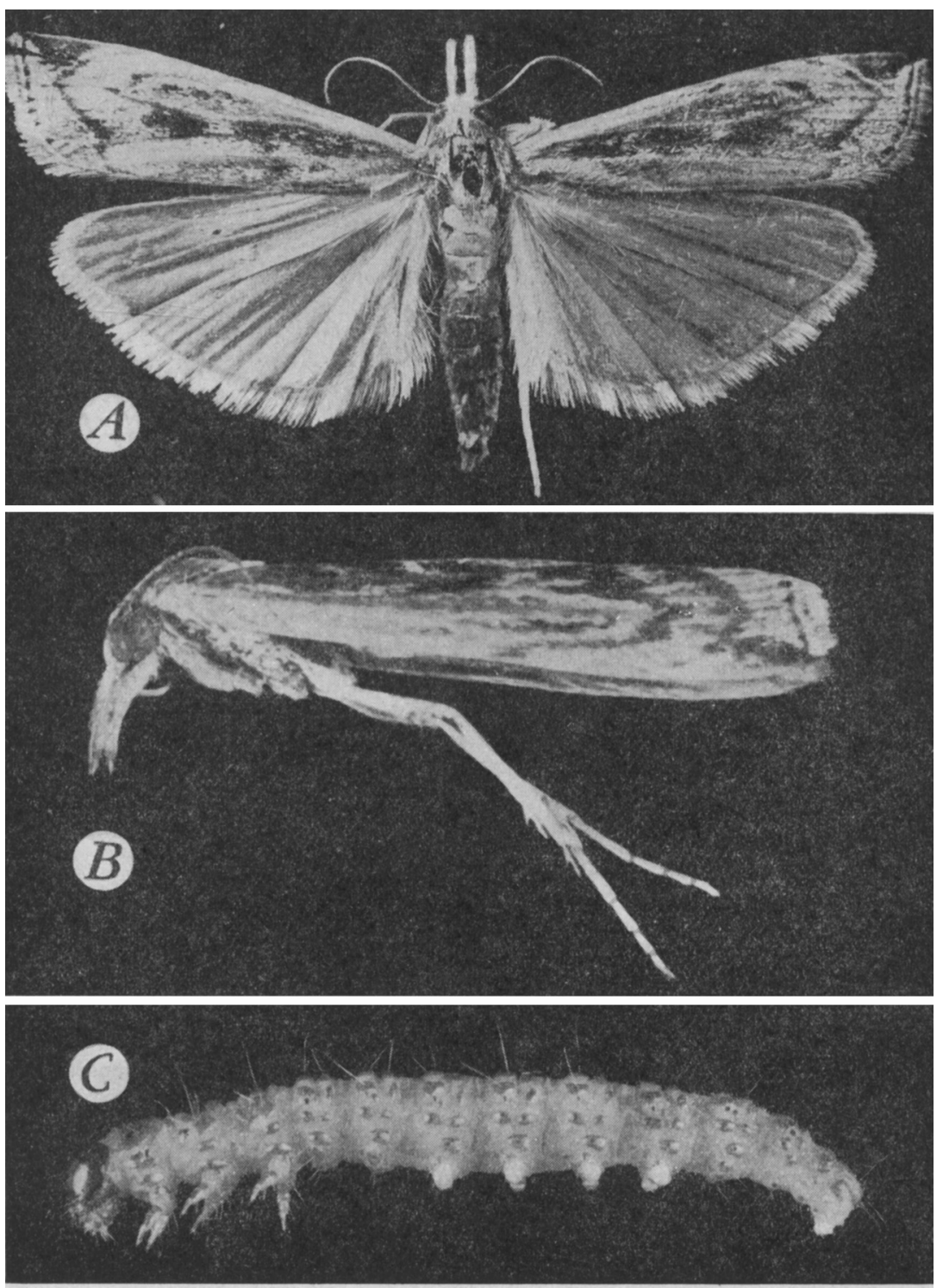

Fig. 2.-Crambus bonifatellus (Hulst): $A$ and $B$, adult female; $C$, sixth-instar larva.

Crambus sperryellus belongs to a group of species having a longitudinal silver stripe on the forewing. C. sperryellus is closely related to C. leachellus Zincken and $C$. occidentalis Grote, which also occur in California. From these, however, it is distinguished by the presence in its forewing of a distinct whitish or yellowish-white shade connecting the proximal end of the forewing stripe with the outer wing margin (fig. $6, A$ and $B$ ). 
Common Names.-Through newspapers, garden magazines, and insecticide salesmen the two California species of lawn-infesting Crambus have become well known as "lawn moths." No distinction has been made between them, however, even though the adults are readily identified by their color pattern. They will here be designated as the fawn-colored lawn moth (C. bonifatellus) and the silver-barred lawn moth (C. sperryellus).
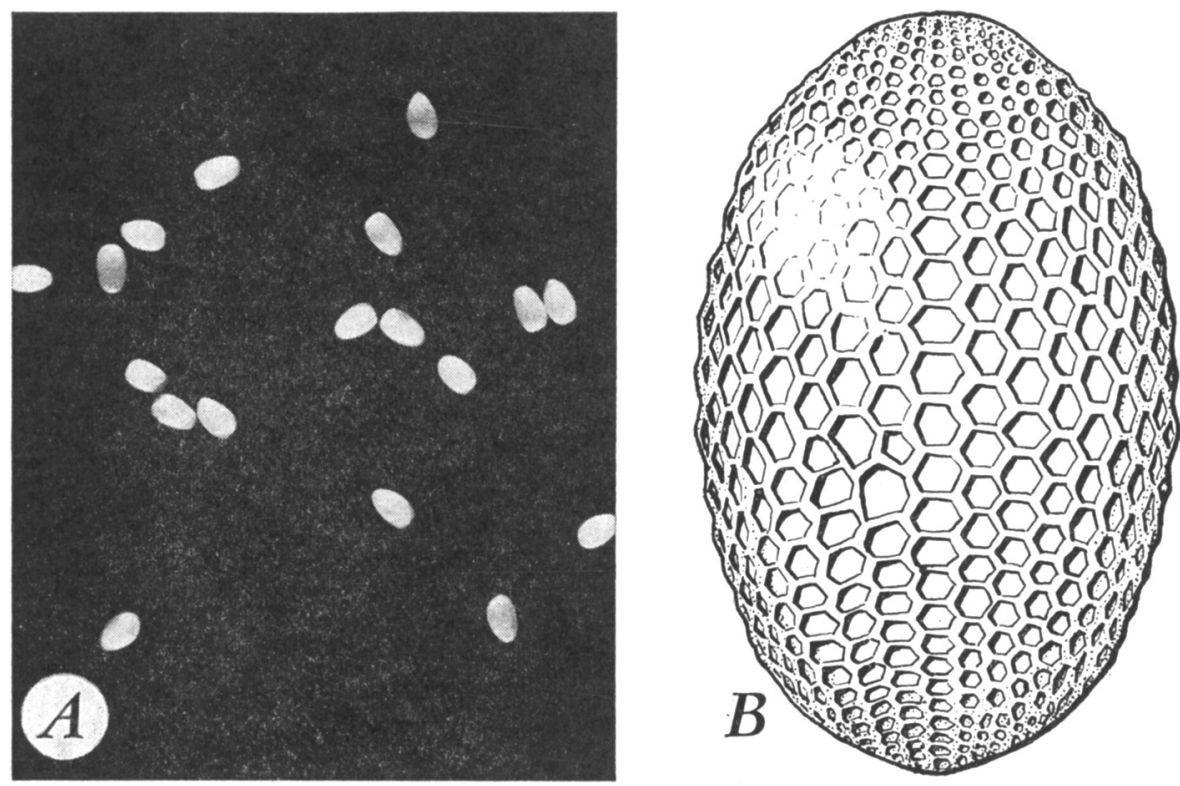

Fig. 3.-A, Eggs of Crambus bonifatellus (enlarged); $B$, drawing of egg, much enlarged to show the sculpture of the chorion.

\section{TECHNICAL DESCRIPTION OF STAGES OF CRAMBUS BONIFATELLUS}

Adult Female.-(Fig. 2, $A$ and $B$ ) Ground color of forewing and body in general creamy buff, ground color of hind wing somewhat more silvery; forewing with three irregular and partially connected spots along basal half of cubitus, an irregular streak or spot posterior to and paralleling $R_{5}$, a triangular dark spot apically, a small oblique black spot between $\mathrm{Cu}_{1}$ and $\mathrm{Cu}_{2}$ subapically in the otherwise brown subterminal line, and eight small black spots of terminal line marking ends of veins at wing margin; three to five irregular spots of white scales in discal area of wing; fringe buff and brown. Hind wing with silvery buff ground color overlaid with scattered grayish-brown scales becoming thicker apically; fringe silvery gray. Wing expanse 20 to $23 \mathrm{~mm}$.

Adult Male.-Markings as in female except that ground color of forewing and body in general is buff brown, a black streak along basal half of cubitus is less distinct, fringe of forewing is mostly brownish, hind wing has a darker cast and its fringe is darker. Antenna not pectinate, but twice as thick as that of female; wing expanse 17 to $20 \mathrm{~mm}$. For the genitalia, see also figure $5, D, E$, and $F$. Tegumen broadly convex. Uncus stout, $1 \frac{1}{2}$ times as long as gnathos; with a short sharp downward-pointing apex; a few short hairs beneath a clump of hairs basally above. Gnathos slender, almost straight in lateral view, and bare. Upper portion of clasper membranous and thickly covered with long hairs, separated from lower portion except basally; lower portion sclerotized and with a pair of long spinelike processes that curve toward each other, the inner (and more basal) process being slightly 


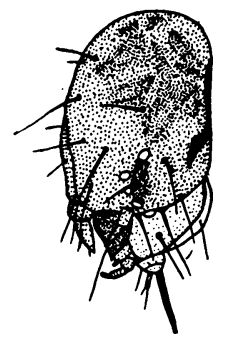

$A$

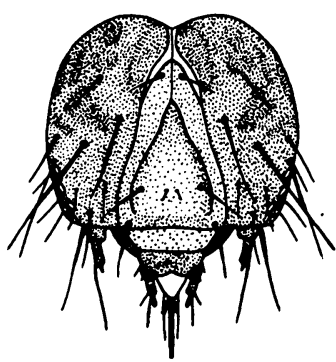

$B$

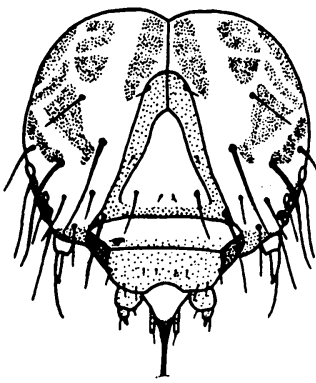

C

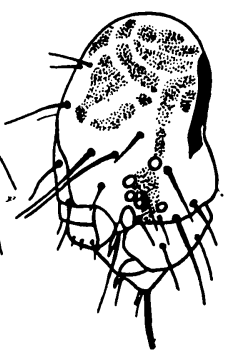

D
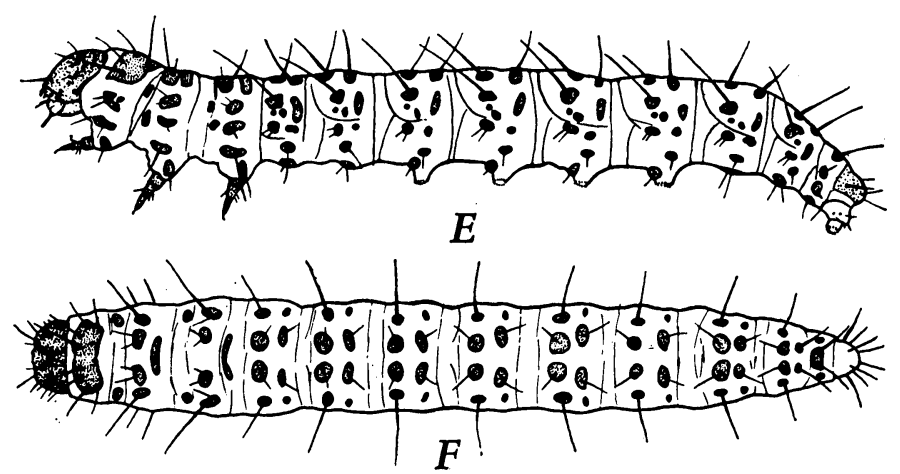
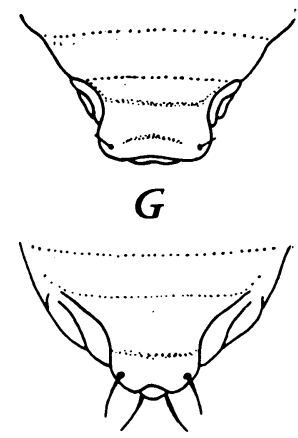

I

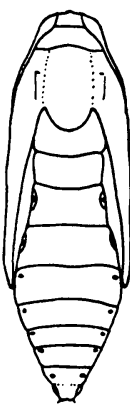

$J$

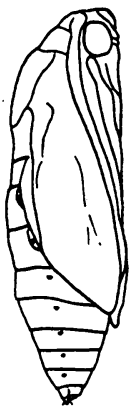

K

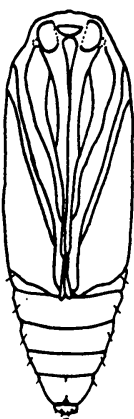

$L$
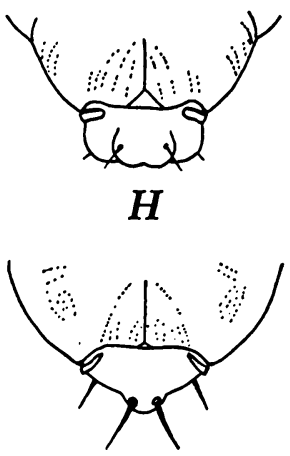

M

Fig. 4.-A, $B, E-H, J-L, C r a m b u s$ bonifatellus: $A, B$, lateral and frontal views of head of mature larva ; $E, F$, lateral and dorsal views of mature larva; $G, H$, dorsal and ventral views of abdominal apex of pupa; $J, K, L$, dorsal, lateral, and ventral views of pupa. $C, D, I, M$, $C$. sperryellus: $C, D$, frontal and lateral views of head of mature larva; $I, M$, dorsal and ventral views of abdominal apex of pupa.

the longer and more slender at its base; inner edge of upper process thickly covered with long hairs along its thickened basal half. Aedeagus somewhat longer than claspers, stout, pointed apically, and without hook.

Egg.-(Fig. 3) Elliptical, bluntly rounded at apexes; ornamented with about 35 longitudinal rows of depressed hexagonal plates, some rows incomplete, detail of plates and ribs becoming obscure toward apexes of egg. Color ranging from lemon yellow at deposition through orange to purplish shortly before eclosion. Average length $1.58 \mathrm{~mm}$; average width $1.35 \mathrm{~mm}$. 


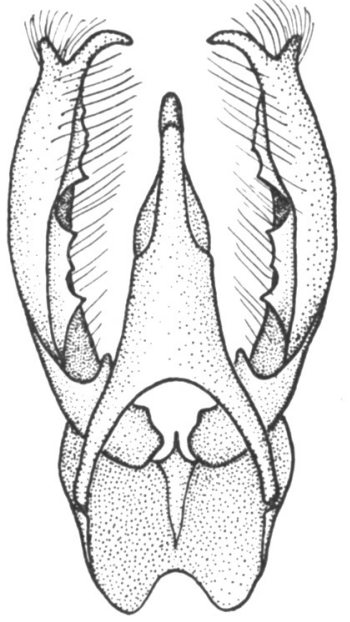

$A$

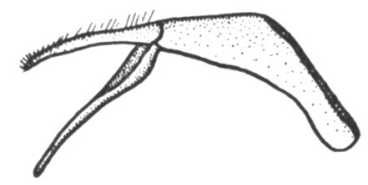

$B$

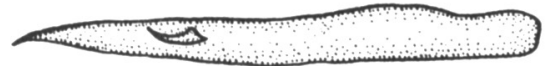

C

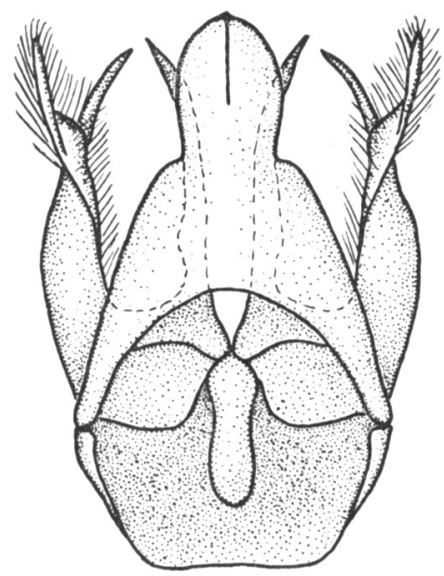

$D$

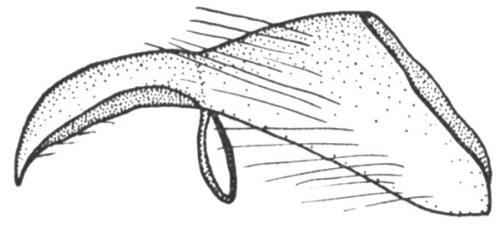

$E$

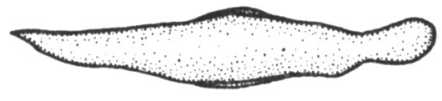

$F$

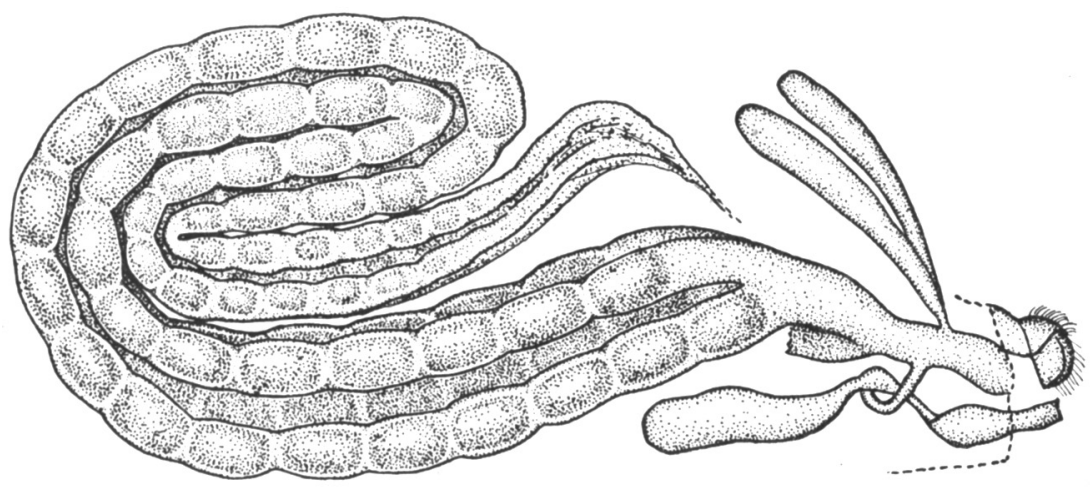

\section{G}

Fig. 5.- $A-C$, Male genitalia of Crambus sperryellus: $A$, parts in natural position, dorsal; $B$, tegumen, lateral; $C$, aedeagus, dorsal. $D-F$, Corresponding male genitalia of $C$. bonifatellus. $G$, Female genital system of $C$. bonifatellus, lateral (one ovary removed). 
The color range through which the egg passes is exceptionally striking. During a 5-day incubation period, the change proceeds as follows: The pure lemon yellow at the time of deposition turns after one day to salmon pink. On the third day a small black eyespot becomes visible near one end, and on the succeeding day the dark larval head and prothorax can be seen taking up the anterior third of the egg. At this time the color is somewhat deeper, and on the following or fifth day it takes on a bluish to purplish cast heralding eclosion.

First Instar.- Head dark brown, legs and caudal plate dusky gray, pronotal plate grayish brown, remainder of body pale orange yellow, with inconspicuous spots. Average body length shortly before molting $1.2 \mathrm{~mm}$; average breadth of head $1.235 \mathrm{~mm}$.

Second Instar. - Similar to preceding instar except for larger size, grayish ground color, appearance of two spots below pronotal shield, and faintly outlined spots around the bases of the body bristles. Average body length shortly before molting $2 \mathrm{~mm}$; average breadth of head $1.336 \mathrm{~mm}$.

Third Instar.-Not appreciably different from the second instar except in size. Average body length shortly before molting $3.5 \mathrm{~mm}$; average breadth of head $1.553 \mathrm{~mm}$.

Fourth Instar.-Body spots faint but distinct; spiracles dark and distinct; otherwise similar to third instar except in size. Average body length shortly before molting $5.5 \mathrm{~mm}$; average breadth of head $1.691 \mathrm{~mm}$.

Fifth Instar.-Body spots well developed, but only moderately dark; body ground color grayish white; head brown to dark brown, with darker markings faintly visible on its upper half; caudal and pronotal plates sprinkled with small dark spots. Average body length shortly before molting $9 \mathrm{~mm}$; average breadth of head $1.936 \mathrm{~mm}$.

Sixth Instar.-(Fig. 2, $C$; fig. 4, $A, B, E$, and $F$ ) Similar to preceding instar except for greater size and darker body spots. Average body length shortly before pupation $15 \mathrm{~mm}$; average breadth of head $1.307 \mathrm{~mm}$.

Seventh and Following Instars.-The seventh and following instars, when they occur, resemble the sixth. Under certain conditions a larva may go through as many as 10 instars; but ordinarily pupation takes place at the end of the sixth.

Pupa.-(Fig. 4, G, $H, J-L$ ) Pale yellow when first formed, but gradually deepening toward brown in color, eyespot becoming almost black shortly before emergence. Oval spiracles present on abdominal segments 3 to 9 , that on 9 faint, those on 3 and 4 enclosed by semicircular lines from hind-wing-case margins, those on 8 and 9 particularly elevated. Caudal process with a roughly trapezoid-shaped dorsal plate, bordered laterally by a depressed and irregularly outlined area; apical margin of dorsal plate with a slightly convex, nearly regular outline; apical angles each with a dorsally directed bristle. Ventrally this process is about as long as broad and bears 2 posteriorly directed bristles, originating subapically close to the middle. Average length of pupa about $8 \mathrm{~mm}$.

\section{TECHNICAL DESCRIPTION OF STAGES OF CRAMBUS SPERRYELLUS}

Adult.-(Fig. 6) Head, palpi above, antennae, forewings beneath, and most of legs, brownish tinted with gold; abdomen above, buff and silver; undersides of palpi, thorax, hind wings, and abdomen silvery white; thorax above, bright golden. Forewing basal to submarginal line bright golden with a broad streak of shining silver, narrowly edged in dark brown and tapered to a point shortly before the submarginal line of dark brown, which is outwardly edged with silver; apex of wing with an indistinctly outlined silver spot and separated from the large silver stripe by a creamy white spot; 5 posterior veins ornamented with narrow blaek spots between submarginal line and brown marginal line; fringe brown and silver. Hind wing silvery gray with a darker edge and silver fringe. Wing expanse, female 21 to $24 \mathrm{~mm}$, male 18 to $21 \mathrm{~mm}$. For the male genitalia, see also figure 5, $A, B, C$. Tegumen slender. Uncus somewhat petiolate, shorter than gnathos, apically rounded and with short backward-pointing bristles that become longer and forward-pointing basally. Gnathos slender, bare, and almost straight in lateral view. Upper portion of clasper membranous, covered with long hairs, and attached for almost its whole length to lower portion; lower portion sclerotized, inner margin sparsely covered with bristles but conspicuously serrate, with about six inward-pointing teeth distributed over the middle two thirds; free 

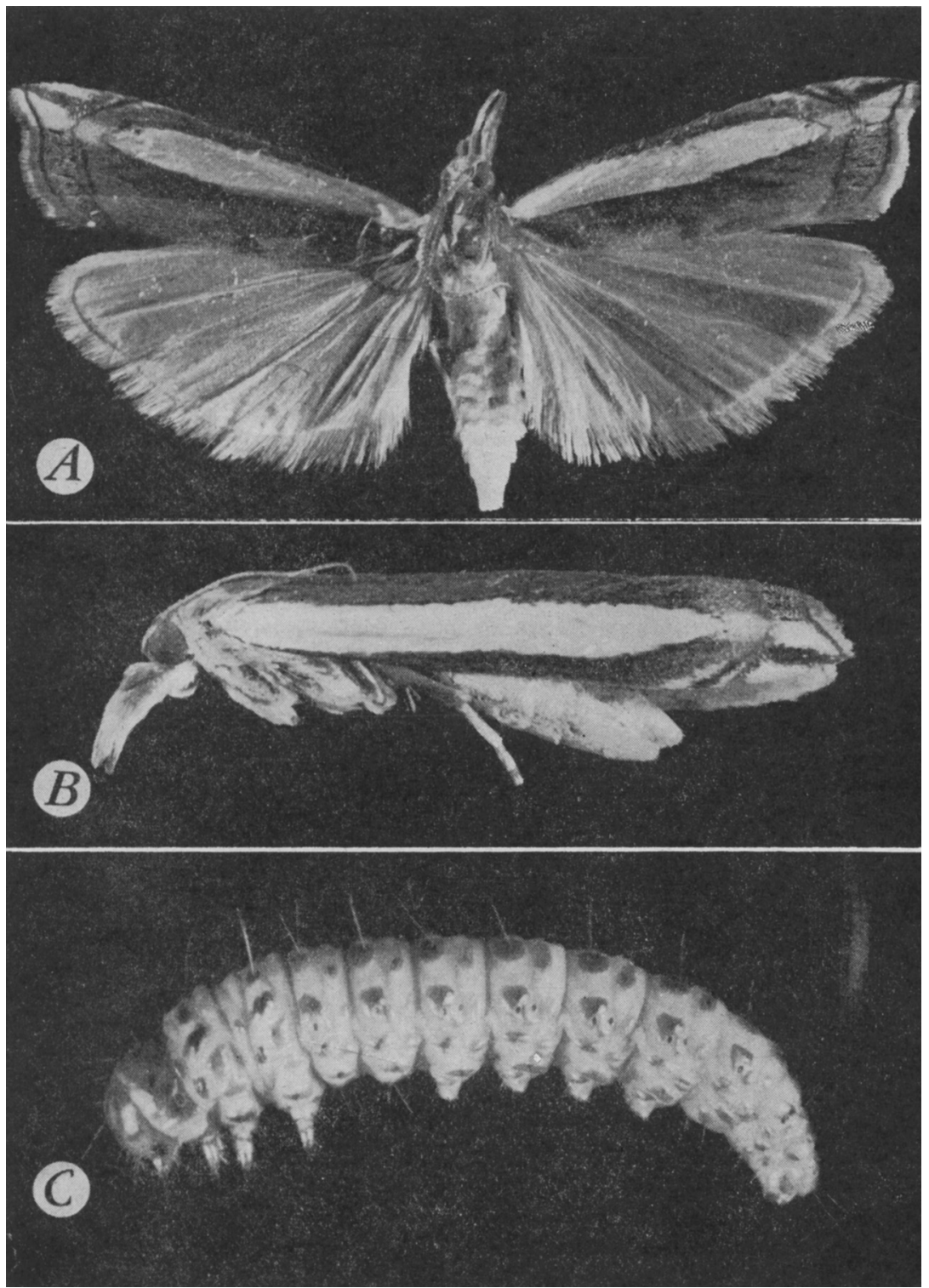

Fig. 6.-Crambus sperryellus Klots: $A$ and $B$, adult female; $C$, seventh-instar larva.

end slender, curved, and narrowly rounded apically. Aedeagus tapering to a sharply pointed apex, with a large curved lateral hooklike process situated at apical third.

Egg.- Similar to that of Crambus bonifatellus in structure, but different in color range during the incubation period. With a 6-day incubation period the lemon-yellow eggs after one day change gradually through pale salmon pink to cherry red near the end of the fourth day. Eyespots are discernible 12 hours later, and the nearly developed larva is visible within its shell after $5 \frac{1}{2}$ days. 
First Instar.-Head dark brown, legs and caudal plate dusky gray, pronotal plate somewhat darker, remainder of body pale orange yellow, body spots inconspicuous. Average body length shortly before molting $1.2 \mathrm{~mm}$; average breadth of head $0.242 \mathrm{~mm}$.

Second Instar.- Not appreciably different from first instar except for the more grayish ground color, larger size, and proportionately smaller head. Average body length shortly before molting $2 \mathrm{~mm}$; average breadth of head $0.351 \mathrm{~mm}$.

Third Instar.- Not appreciably different from second instar except for the more mottled body color and larger size. Average body length shortly before molting $3.5 \mathrm{~mm}$; average breadth of head $0.595 \mathrm{~mm}$.

Fourth Instar.-Body mottled as in previous instar; but spots not distinet, except slightly so on thorax; stigmatal spot black on prothorax, less distinct elsewhere. Head dark brown, with light-brown areas above the eyes and in the region of the frons; legs and pronotal plate dark grayish brown. Average body length shortly before molting $5.5 \mathrm{~mm}$; average breadth of head $0.788 \mathrm{~mm}$.

Fifth Instar.-Body grayish white with distinct grayish-brown spots; head brownish yellow, ornamented on its upper half with flocculent brownish spots; eye region, mandibles, and lateral margin of the head above the eyes, black; caudal plate gray and covered with about 25 small scattered dark spots; pronotal plate with an equal number of similar spots; stigmatal spots black. Average length of the body shortly before molting $9 \mathrm{~mm}$; average breadth of head $1.018 \mathrm{~mm}$.

Sixth Instar.-Similar to fifth instar except for the pale, more whitish body ground color, the paler, more yellowish head ground color, and the larger size. Average length of body shortly before molting $15 \mathrm{~mm}$; average breadth of head $1.325 \mathrm{~mm}$.

Seventh Instar.-(Fig. 4, $C, D ; 6, C$ ) Similar to sixth instar except for greater size and ordinarily lighter ground color of the head. Average length of body shortly before molting $15 \mathrm{~mm}$; average breadth of head $1.708 \mathrm{~mm}$.

Eighth and Following Instars.-Approximating seventh instar in size and markings. Pupation ordinarily takes place after the seventh instar, but under some conditions as many as 9 instars have been observed.

Summary of Differences in Appearance of Crambus Bonifatellus and Crambus Sperryellus.-The adult Crambus bonifatellus, with its spotted gray forewings, differs from C. sperryellus, which has silver-striped forewings. Ample distinction is also afforded by the male genitalia (fig. 5, $A-F$ ). The eggs of the two species appear identical in structure, but differ slightly in color range during incubation. The larvae are practically indistinguishable in the first three instars; but in the fourth and following instars there is a distinct difference in head pigmentation. In C. sperryellus the dark spots on the upper half of the head contrast strongly with the light background; but in $C$. bonifatellus the spots are indistinct, and the ground color is usually brown or nearly black. The pupae of the two species have distinctive caudal processes. That of $C$. bonifatellus is blunt (fig. $4, G, H$ ), whereas that of $C$. sperryellus is roundly pointed (fig. $4, I, M$ ).

\section{LIFE HISTORY AND HABITS OF CRAMBUS BONIFATELLUS}

Adult.-Judging from laboratory specimens, emergence from the pupa takes place in late afternoon or evening, and females cannot lay fertile eggs until two nights later. Copulation has not been noted; it apparently does not occur in flight, for the writer has observed and captured thousands of flying specimens throughout the season without seeing any copulating pairs.

Neither sex appears to be attracted to flowers nor to take any food under 
natural conditions. In captivity, however, the moths eagerly drink water or sugar solution.

The average life span of Crambus bonifatellus collected in the field was 4.2 days at $75^{\circ} \mathrm{F}$ under natural light conditions. When the temperature was lowered to $59^{\circ}$ and $41^{\circ}$, longevity was increased to an average of 13.6 and 14.0 days respectively.

Perhaps the most characteristic action of lawn moths is their oviposition flight. Just at dusk during the flight season the females begin to leave their hiding places in grass or shrubbery and appear over lawns. For about an hour they maintain a hovering, undulating flight, during which they are rarely

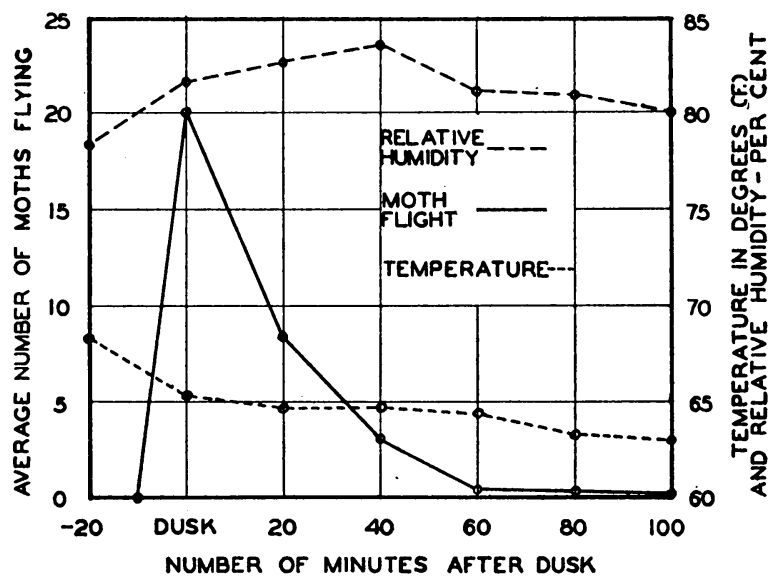

Fig. 7.-Flight of Crambus bonifatellus in relation to time of day, temperature, and relative humidity, computed from average figures of weekly observations, June 17 to September 16,1941 , on a Los Angeles lawn. An area of 1,000 square feet was taken as a unit.

more than a foot above the grass. In the laboratory moths were observed to drop their eggs as they fluttered in glass jars. The eggs are not adhesive and are dropped either in flight or at rest.

The oviposition flight appears to depend chiefly on natural light conditions. Weekly observations during the summer of 1941 revealed no correlation between the time or extent of the flight and the temperature or humidity. Figure 7 summarizes these data. The flight reaches a peak at dusk and falls off rapidly thereafter. Twenty minutes after dusk it has decreased by approximately half, and 40 minutes after dusk it has again decreased by half. Except for a few stragglers it lasts only an hour. In the latter part of this period, moths usually flutter above shrubbery at the edge of the lawn. These are predominantly males, which rarely fly in the open. During oviposition the moths invariably concentrate where the grass is most lush. Similarly, largest numbers in any one locality are usually found over the new and tender lawns. This habit may partially explain the disproportionate damage to the lush bent grass in areas where Bermuda or bluegrass predominates.

Though both sexes are mildly attracted to lights, the attraction appears to be ineffective until oviposition is nearly over. Even when moths are abundant, relatively few gather about street or porch lights. 
Oviposition data from moths collected in the field are summarized in table 3 , and presented graphically in figure 8. Eggs were counted for 100 moths kept at about $75^{\circ} \mathrm{F}$ and exposed to natural light in the laboratory. Relatively few eggs were laid on the night of capture, probably because of the upset to the moth's routine. The largest number were laid the next night after capture, with an average of 74.4. The average total number per moth was 187.3. Of the 100 moths, 18 per cent laid more than 300 eggs; and one moth produced 587 over a week's period, with 211 in a single night.

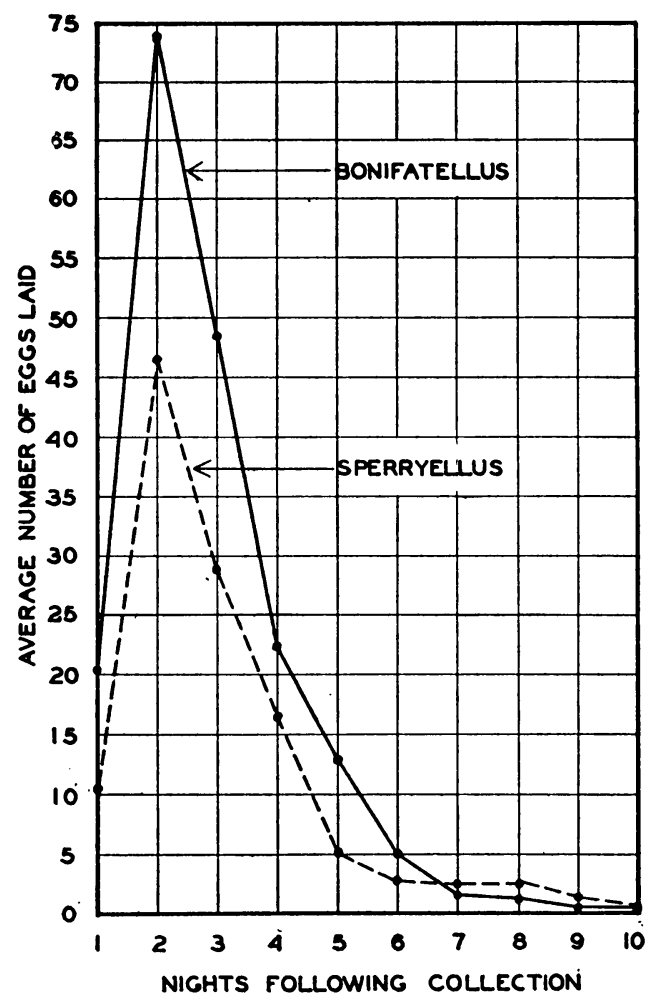

Fig. 8.-Comparison of the oviposition of Crambus bonifatellus and C. sperryellus collected in the field. One hundred specimens each were kept in shell vials at room temperature $\left(73^{\circ}-77^{\circ} \mathrm{F}\right)$ under natural light conditions.

Several females collected in the field were dissected for a study of the reproductive system (fig. $5, G$ ). Dissections were also made of moths that had laid a full quota. In these, only 1 or 2 well-formed eggs were found in the ovarioles; and the ovaries appeared to be degenerating.

Certain effects of temperature, light, and food on egg production were studied. Moths kept in the dark at constant temperatures laid an average of 6 eggs at $41^{\circ} \mathrm{F}, 170$ at $59^{\circ}$, and 102 at $75^{\circ}$. Those in natural light at about $75^{\circ}$ laid an average of 187 eggs. Apparently, then, natural light conditions favor egg production, and the total number of eggs is not much affected by temperatures as low as $59^{\circ}$. 
Egg.-The incubation period varies according to the temperature. Eggs kept at $41^{\circ} \mathrm{F}$ did not develop, although they remained viable for 74 days. The incubation period at $59^{\circ}$ was 15 days; at $75^{\circ}$ it was 4.5 ; and at $86^{\circ}$ or $98^{\circ}$ it was 3.5. These data, as related to egg coloration, are given in table 4 .

In rearing experiments, a high percentage of the eggs from females collected in the field proved to be fertile. Of 1,407 eggs laid by 14 moths captured at various times during the summer, 1,400, or 99.5 per cent, hatched. Evidently,

TABLE 3

Oviposition Data on 100 Moths Each of Crambus bonifatellus and C. sperryellus, COLLECTED IN THE FIELD*

\begin{tabular}{|c|c|c|c|c|c|c|c|}
\hline \multirow{2}{*}{ Species } & \multirow{2}{*}{$\begin{array}{c}\text { Average } \\
\text { number } \\
\text { of } \\
\text { eggs } \\
\text { laid }\end{array}$} & \multicolumn{6}{|c|}{ Number of moths ovipositing in each range given } \\
\hline & & $\begin{array}{c}1-100 \\
\text { eggs }\end{array}$ & $\begin{array}{c}101-200 \\
\text { eggs }\end{array}$ & $\begin{array}{c}201-300 \\
\text { eggs }\end{array}$ & $\begin{array}{c}\text { 301-400 } \\
\text { eggs }\end{array}$ & $\begin{array}{c}401-500 \\
\text { eggs }\end{array}$ & $\begin{array}{l}501-600 \\
. \text { eggs } \\
\end{array}$ \\
\hline C. bonifatellus. & $\begin{array}{l}\text { eggs } \\
187\end{array}$ & $\begin{array}{c}\text { moths } \\
28\end{array}$ & $\begin{array}{c}\text { moths } \\
28\end{array}$ & $\begin{array}{c}\text { moths } \\
26\end{array}$ & $\begin{array}{c}\text { moths } \\
14\end{array}$ & $\begin{array}{c}\text { moths } \\
3\end{array}$ & $\begin{array}{c}\text { moths } \\
1 \dagger\end{array}$ \\
\hline C. sperryellus. & 118 & 45 & 37 & 13 & 4 & 0 & $1 \ddagger$ \\
\hline
\end{tabular}

* The moths were kept at a laboratory temperature of $73^{\circ}$ to $77^{\circ} \mathrm{F}$.

+ This specimen laid 587 eggs in 6 days.

$\ddagger$ This specimen laid 528 eggs in 8 days.

TABLE 4

Relation of Changes in Egg Color to Time and Temperature in the InCUBATION PERIOD OF Crambus bonifatellus

\begin{tabular}{|c|c|c|c|c|c|c|}
\hline $\begin{array}{c}\text { Degrees Fahrenheit } \\
\text { (constant temperature) }\end{array}$ & \multicolumn{5}{|c|}{ Time in stages of incubation* } & $\begin{array}{c}\text { Total } \\
\text { incubation } \\
\text { period }\end{array}$ \\
\hline 41. & 8.0 & 12.0 & $74.0 \dagger$ & $\ldots$ & $\cdots$ & $\ldots$ \\
\hline 59. & 2.0 & 5.0 & 2.5 & 4.0 & 1.5 & 15.0 \\
\hline $75 \ldots$ & 1.0 & 0.5 & 1.5 & 1.0 & 0.5 & 4.5 \\
\hline $86 \ldots$ & 0.75 & 0.5 & 1.0 & 0.75 & 0.5 & 3.5 \\
\hline $98 \ldots \ldots \ldots \ldots \ldots \ldots$ & 0.75 & 0.5 & 1.0 & 0.75 & 0.5 & 3.5 \\
\hline
\end{tabular}

* Based on an average of 3 tests of 100 eggs each for each temperature.

$\dagger$ Eggs shriveled and molded at this time without developing further.

however, a certain amount of moisture is required during incubation. More than 1,000 eggs kept in a cotton-stoppered shell vial without additional moisture produced only 5 larvae. At the other extreme, only 6 larvae emerged from 25 eggs completely immersed in water during incubation. Practically 100 per cent hatched when the eggs were kept on moist blotter paper, as in the records mentioned at the beginning of the paragraph, or when they were placed on dry blotter paper and watered daily. In another test, of 1,250 eggs that were floated on water throughout incubation, 98 per cent hatched.

Eggs were obtained from several moths reared in the laboratory. As would be expected, virgin females produced infertile eggs, which shriveled a few days later without changing color. Attempts were made to insure fertilization by mating virgin females with freshly emerged males. Although copulation was not observed, one female did lay fertile eggs 2 days after being confined with a male. 
Larva.-Previous authors have commented on the difficulty of rearing Crambus in the laboratory. It is not easy to provide the requirements of fresh grass, moderately high humidity without condensed moisture, and freedom from mold, while closely observing the life history. In consequence, several methods of rearing were tried before a satisfactory one was developed. At first individual larvae were placed in small, slender glass vials stoppered with cotton. This method proved impractical because of the difficulty of maintaining proper humidity and cleanliness. Second, transplanted grass in small flowerpots was artifically infested with eggs, and the larval development was followed as closely as possible. Accurate observations could not, however, be

TABLE 5

Larval Head-Breadth Measurements* of Crambus bonifatellus and C. sperryellus Compared With THE TheORETICAI, MEASUREMents CoMputed AcCording To Dyar's LaW

\begin{tabular}{|c|c|c|c|c|}
\hline \multirow[b]{2}{*}{ Instar } & \multicolumn{2}{|c|}{ Crambus bonifatellus } & \multicolumn{2}{|c|}{ Crambus sperryellus } \\
\hline & $\begin{array}{c}\text { Actual } \\
\text { breadth }\end{array}$ & $\begin{array}{c}\text { Theoretical } \\
\text { breadth, } \\
\text { factor }=1.43\end{array}$ & $\begin{array}{c}\text { Actual } \\
\text { breadth }\end{array}$ & $\begin{array}{c}\text { Theoretical } \\
\text { breadth, } \\
\text { factor }=1.43\end{array}$ \\
\hline $1 \ldots$ & $\begin{array}{c}m m \\
0.235\end{array}$ & $\begin{array}{c}m m \\
0.235\end{array}$ & $\begin{array}{c}m m \\
0.242\end{array}$ & $\begin{array}{c}m m \\
0.242\end{array}$ \\
\hline $2 \ldots \ldots$ & 0.364 & 0.336 & 0.351 & 0.351 \\
\hline $3 \ldots \ldots$ & 0.553 & 0.481 & 0.595 & 0.493 \\
\hline $4 \ldots \ldots \ldots \ldots \ldots \ldots \ldots$ & 0.691 & 0.688 & 0.788 & 0.705 \\
\hline $5 \ldots \ldots \ldots \ldots \ldots \ldots \ldots \ldots$ & 0.936 & 0.984 & 1.018 & 1.008 \\
\hline $6 \ldots \ldots \ldots \ldots \ldots \ldots \ldots$ & 1.307 & 1.401 & 1.325 & 1.441 \\
\hline $7 \ldots \ldots \ldots \ldots \ldots \ldots \ldots$ & $\ldots \ldots$ & $\ldots \ldots$ & 1.708 & 2.060 \\
\hline
\end{tabular}

* Measurements based on an average of 10 specimens each reared in the laboratory.

made; and only a general idea of the life history and the amount of feeding was obtained. In the method finally employed, the bottoms of small stender dishes were lined with several layers of close-fitting damp blotter paper. Fifteen newly hatched larvae were placed in each dish; as they increased in size, the number was reduced to prevent overcrowding. Each dish was examined daily, thoroughly cleaned, and supplied with fresh-cut grass. Enough water was added to keep the blotter lining damp, and the dishes were kept in the dark to approximate the natural conditions.

Records of the instars were obtained by noting the characteristically swollen premolt condition and by collecting the cast head capsules. Unlike Crambus praefectellus Zinck., as recorded by Ainslee (1923b), the larvae consumed neither these capsules nor the eggshells. Table 5 gives measurements of the cast head capsules. The increase in head size roughly follows a geometrical progression with a factor of 1.43 .

Figure 9 shows the types of damage done by the different larval stages. The first two instars work chiefly as skeletonizers of the grass blades. Usually they begin feeding on the upper surface of the leaf, but avoid the veins. All stages spin silken shelters camouflaged with bits of grass and excrement. In the first two instars these shelters must be built on a single leaf blade. Older larvae may utilize several blades of grass in constructing their homes. When disturbed, young larvae readily drop to the ground by suspending themselves on an anal 
thread. Larvae of all sizes can curl into a compact ball when danger threatens ; but after the third molt they more often depend on their agility for escape. They crawl backward as rapidly as forward and, if touched along the side of the body by any moving object, will thresh wildly about. In this respect $\mathrm{Cram}$ bus bonifatellus is much more sensitive than C. sperryellus.

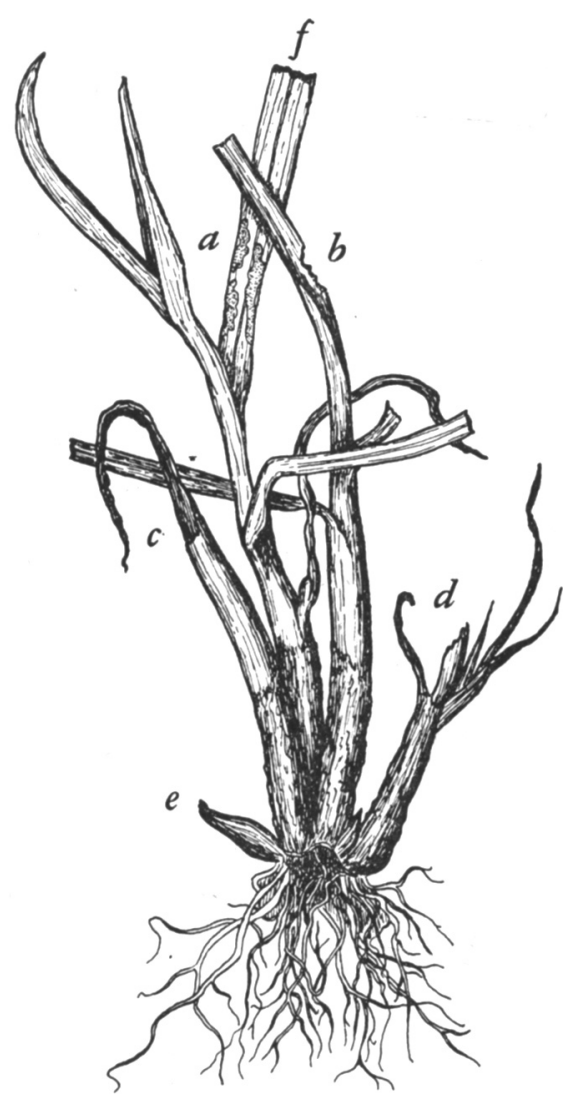

Fig. 9.-Typical injury to bent grass by Crambus larvae; $a$, skeletonizing by firstinstar larvae; $b$, leaf-notching by third- or fourth-instar larvae; $c-e$, young shoots fed upon by larvae; $f$, entire end of blade removed by mature larva.

Third-instar and older larvae notch the edges of grass and often sever the blades completely, afterwards drawing them into the shelters to be consumed at leisure. Though this latter process can occasionally be seen in the daytime, feeding is much more evident at night. The writer observed night feeding between $8: 00$ and $10: 00$ p.m., September 2,1940 , on a heavily infested lawn. With the aid of a flashlight he saw the larvae cutting grass and drawing it into their burrows. A telltale waving of a grass blade gave the first indication of a webworm's presence. A direct ray of light or the slightest movement of the observer halted the work up to several yards away. The larvae particularly relish the fresh tender grass shoots and will chew these back as rapidly as they appear. They also attack the greener portions of the crown, but, contrary to popular opinion, they do not molest the grass roots. This observation agrees with those made by Ainslee $(1923 a, 1923 b, 1930)$ on Crambus mutabilis Clemens, C. praefectellus, and $C$. teterrellus Zinck. and by Jewett (1939) on C. mutabilis, C. teterrellus, and $C$. trisectus Walker. Fresh sodwebworm frass is invariably a bright grass green, which would not be its color if the larvae were feeding on the nearly colorless grass roots. To obtain some definite information on this point, fourth- and fifth-instar larvae were placed in dishes containing a few bluegrass blades and crowns, and a large quantity of fresh grass roots. The grass blades were eaten at once, and also the greener portions of the crown. After 3 days all green material had been consumed. Although fresh roots were provided daily, no evidence of feeding on them could be discerned even after several days' starvation.

Well-grown larvae consume considerable grass. According to records made at $75^{\circ} \mathrm{F}$, fifth-instar larvae eat about twice their weight of bluegrass daily. 
Molting takes place within the protecting confines of a silken shelter. A premolt period beginning about 12 hours before ecdysis $\left(\right.$ at $\left.75^{\circ} \mathrm{F}\right)$ is marked by a swollen appearance, especially in the neck region. At this time the larva is quiescent, takes no food, and cannot crawl freely.

\section{TABLE 6}

Length of Time in Each Period in the Life Cycle of Crambus bonifatellus at Different Temperatures with Bluegrass Blades as Larval Food

\begin{tabular}{|c|c|c|c|c|c|c|c|c|c|c|c|c|}
\hline \multirow{2}{*}{$\underset{\substack{\text { Degrees } \\
\text { Fahren- }}}{\text { heit }}$} & \multicolumn{3}{|c|}{ Egg } & \multicolumn{3}{|c|}{ Larva } & \multicolumn{3}{|c|}{ Pupa } & \multicolumn{3}{|c|}{ Total } \\
\hline & $\begin{array}{l}\text { Mini- } \\
\text { mum }\end{array}$ & $\begin{array}{l}\text { Aver- } \\
\text { age* }\end{array}$ & $\begin{array}{l}\text { Maxi- } \\
\text { mum }\end{array}$ & $\begin{array}{l}\text { Mini- } \\
\text { mum }\end{array}$ & $\begin{array}{l}\text { Aver- } \\
\text { age }^{*}\end{array}$ & $\begin{array}{l}\text { Maxi- } \\
\text { mum }\end{array}$ & $\begin{array}{l}\text { Mini- } \\
\text { mum }\end{array}$ & $\begin{array}{c}\text { Aver- } \\
\text { age* }\end{array}$ & $\begin{array}{l}\text { Maxi- } \\
\text { mum }\end{array}$ & $\begin{array}{l}\text { Mini- } \\
\text { mum }\end{array}$ & $\begin{array}{c}\text { Aver- } \\
\text { age* }\end{array}$ & $\begin{array}{l}\text { Maxi- } \\
\text { mum }\end{array}$ \\
\hline & days & day 8 & days & days & days & days & days & days & days & days & days & days \\
\hline $41 \ldots \ldots$ & $\ldots \dagger$ & $\ldots . \dagger$ & $\ldots . \dagger$ & & & & & & & & & \\
\hline $59 \ldots \ldots$ & 14.0 & 15.0 & 16.0 & 82.0 & 91.7 & $120.0 \ddagger$ & 27.0 & 27.0 & 27.0 & 123.0 & 133.7 & 163.0 \\
\hline $75 \ldots \ldots$ & 4.5 & 4.5 & 4.5 & 18.0 & 23.78 & 42.0 & 6.0 & 7.7 & 11.0 & 28.5 & 35.9 & 67.5 \\
\hline $86 \ldots \ldots$ & 3.5 & 3.5 & 3.5 & 17.0 & 22.7 & 30.0 & 7.0 & 7.0 & 7.0 & 27.5 & 33.2 & 40.5 \\
\hline $98 \ldots \ldots$ & 3.5 & 3.5 & 3.5 & $\ldots+\dagger$ & $\ldots t$ & $\ldots \dagger$ & $\ldots$ & $\ldots$ & $\ldots$ & $\ldots$ & $\ldots$ & $\ldots$ \\
\hline
\end{tabular}

* Averages were based on 200 eggs at each temperature; 9 larvae at $59^{\circ} \mathrm{F}, 7$ larvae at $86^{\circ}, 75$ larvae at $75^{\circ}$ 1 pupa at $59^{\circ}, 63$ pupae at $75^{\circ}, 4$ pupae at $86^{\circ}$.

$\dagger$ Specimens died before completing this period.

† Two larvae that died before pupation had lived 141 and 149 days. 33 days.

Two specimens reared out of doors at temperatures of $55^{\circ}$ to $87^{\circ} \mathrm{F}$ completed the larval period in 31 and

\section{TABLE 7}

Relation of Changes in Egg Color to Time and Temperature in the InCUBATION PERIOD OF Crambus sperryellus

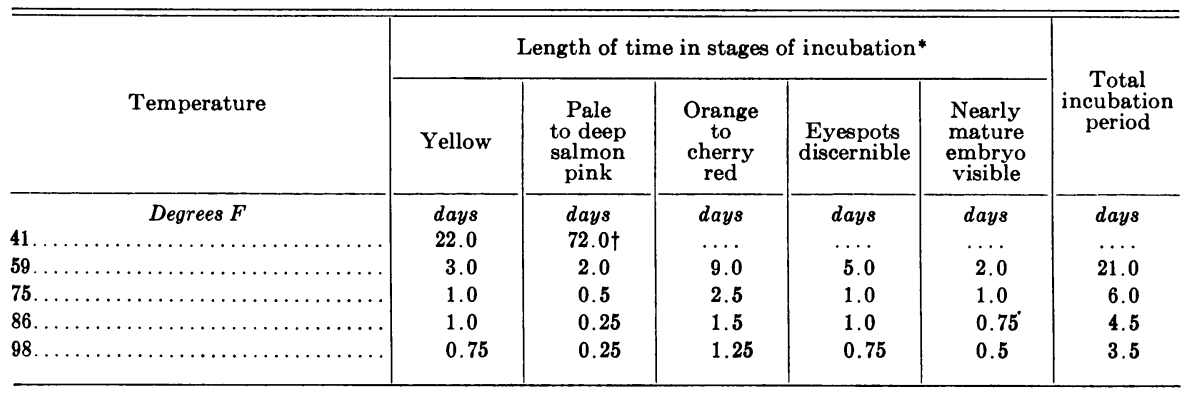

* Based on an average of 2 tests of 100 eggs each for each temperature.

$\dagger$ Eggs shriveled and molded at this time without developing further.

The duration of the various larval stages varies with the temperature. At approximately $75^{\circ} \mathrm{F}$, with bluegrass as food, there are normally six larval instars, the first five of which average $3 \frac{1 / 2}{2}$ days each in length. The sixth instar averages 6 days. Table 6 gives figures on the complete larval period of Crambus bonifatellus reared in the laboratory at various constant temperatures. At $41^{\circ}$ and $98^{\circ}$ no larvae were reared to maturity. At $86^{\circ}$ and $75^{\circ}$ the larvae showed a pronounced tendency toward cannibalism, which was not at all evident among those reared at $59^{\circ}$.

Pupa.-After the last-stage larva has stopped feeding, it reinforces the silken larval shelter and pupates within it. Transformation is slow; the larva lies quiescent for 2 or 3 days before quickly shedding its skin. After this 
process the split head capsule and a bit of crumpled skin are all that remains of the larval integument. The pupa is usually found within the top inch of soil. Figure 10 shows a piece of sod cut to expose the cocoon in its natural position. The length of the pupal stage depends upon the temperature. Laboratory specimens emerged after 27 days at $59^{\circ} \mathrm{F}, 6$ to 11 days (average 7.7 ) at $75^{\circ}$, and 7 days at $86^{\circ}$. The pupal period was practically the same for both sexes at $75^{\circ}$, the only temperature at which an appreciable number of pupae were available. The average pupal period for 33 females was 7.8 days; for 30 males, 7.6.

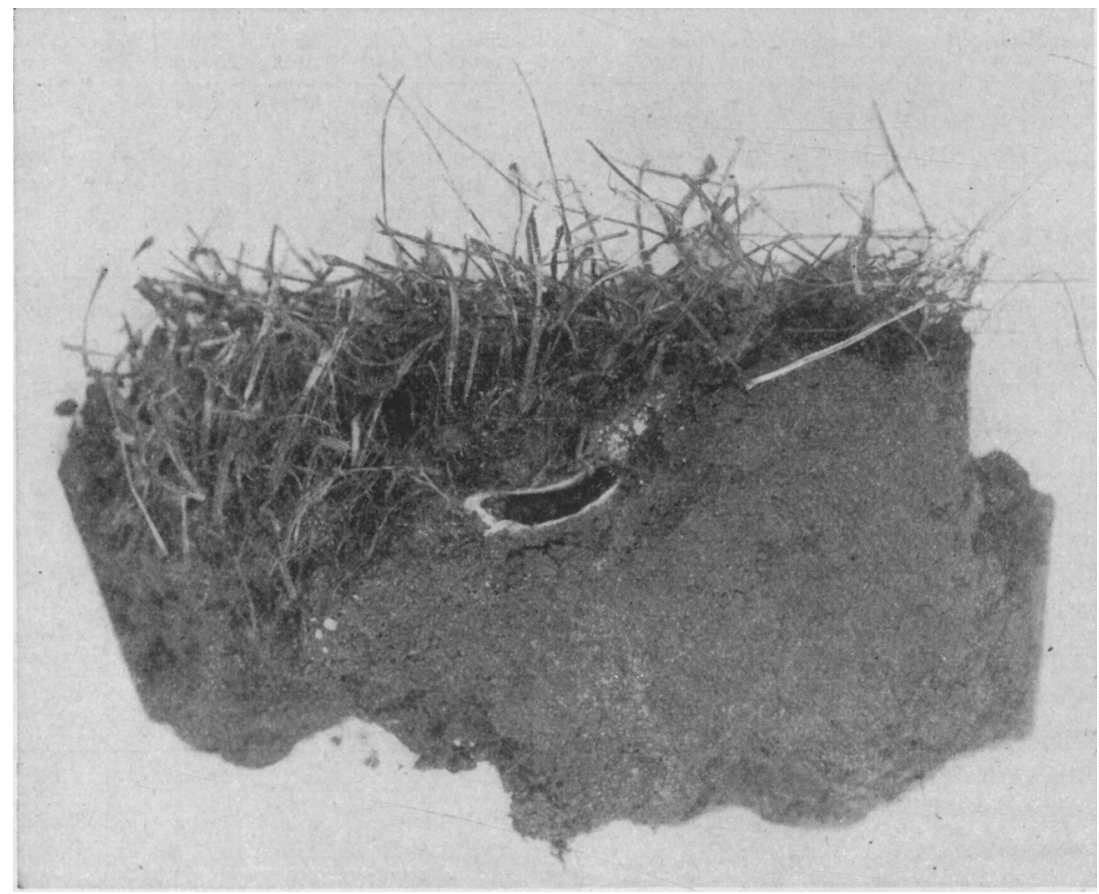

Fig. 10.- Section of sod cut to expose cocoon and pupa of Crambus bonifatellus. (Natural size.)

\section{LIFE HISTORY AND HABITS OF CRAMBUS SPERRYELLUS}

Apparently the habits and general life history are much the same in Crambus sperryellus as in $C$. bonifatellus. Since the latter has been discussed in detail, only the differences between the two need now be pointed out.

Adult.-Crambus sperryellus lived longer in captivity than $C$. bonifatellus at all temperatures used except $41^{\circ} \mathrm{F}$. It laid far fewer eggs, howeverespecially at $59^{\circ}$, when an average of only 15 eggs were laid as compared with 170 for C. bonifatellus.

Daily egg counts were made of 100 moths collected in the field and kept at about $75^{\circ} \mathrm{F}$ under natural light conditions in the laboratory. Figure 8 is a 
graph of the results. The curve parallels that of Crambus bonifatellus closely, but at lower levels.

The first night there was an average of 11.2 eggs. The second night the largest number was laid, namely 46.7 . The average total number was 118 , as opposed to 187 for $C$. bonifatellus. Of the 100 moths, only 5 laid more than 300 eggs $(310,310,311,323,528)$; and only 13 laid from 200 to 300 . Table 3 (p. 282.) summarizes these data.

Egg.-Table 7 correlates the changes of egg color with time and temperature during incubation. Judging from these data, under natural summer lawn temperatures of about $55^{\circ}$ to $85^{\circ} \mathrm{F}$ the incubation period of $C$. sperryellus would be 2 or 3 days longer than that of $C$. bonifatellus (see also table 8). The fertility of $C$. sperryellus eggs is indicated by the 100 per cent hatch of 420 eggs laid by 6 females collected in the field.

\section{TABLE 8}

Length of Time in Each Period in the Life Cycle of Crambus sperryellus at Different Temperatures with Bluegrass Blades as Larval Food

\begin{tabular}{|c|c|c|c|c|c|c|c|c|c|c|c|c|}
\hline \multirow{2}{*}{$\begin{array}{l}\text { Tem- } \\
\text { pera- } \\
\text { ture }\end{array}$} & \multicolumn{3}{|c|}{ Egg } & \multicolumn{3}{|c|}{ Larva } & \multicolumn{3}{|c|}{ Pupa } & \multicolumn{3}{|c|}{ Total } \\
\hline & $\begin{array}{l}\text { Mini- } \\
\text { mum }\end{array}$ & $\begin{array}{l}\text { Aver- } \\
\text { age* }\end{array}$ & $\begin{array}{l}\text { Maxi- } \\
\text { mum }\end{array}$ & $\begin{array}{l}\text { Mini- } \\
\text { mum }\end{array}$ & $\begin{array}{l}\text { Aver- } \\
\text { age* }\end{array}$ & $\begin{array}{l}\text { Maxi- } \\
\text { mum }\end{array}$ & $\begin{array}{l}\text { Mini- } \\
\text { mum }\end{array}$ & $\underset{\text { age* }}{\text { Aver- }}$ & $\begin{array}{l}\text { Maxi- } \\
\text { mum }\end{array}$ & $\begin{array}{l}\text { Mini- } \\
\text { mum }\end{array}$ & $\begin{array}{c}\text { Aver- } \\
\text { age* }\end{array}$ & $\underset{\text { mum }}{\text { Maxi- }}$ \\
\hline Deg. F & days & days & days & days & days & days & days & days & days & days & days & days \\
\hline $41 \ldots \ldots$ & & & & & & $\ldots$ & $\ldots$ & $\ldots$ & $\ldots$ & $\ldots$ & $\ldots$ & $\ldots$ \\
\hline 59 . & 21.0 & 21.1 & 22.0 & $\ldots \dagger^{\dagger}$ & $\ldots \dagger$ & $\ldots \dagger$ & $\ldots$ & $\ldots$ & $\ldots$ & $\ldots \ldots$ & $\ldots$ & $\ldots$ \\
\hline 75 . & 5.5 & 6.0 & 6.5 & 27.0 & 37.6 & 54.0 & 10.0 & 11.2 & 13.0 & 42.5 & 54.8 & 73.5 \\
\hline $86 \ldots \ldots$ & 4.5 & 4.5 & $\ldots \dagger$ & $\ldots+t$ & $\ldots+\dagger$ & $\ldots$ & $\ldots$ & $\ldots$ & $\ldots$ & $\ldots$ & $\ldots$ & $\ldots$ \\
\hline $98 \ldots \ldots$ & 3.5 & 3.5 & $\ldots t$ & $\ldots \dagger$ & $\ldots+\dagger$ & $\ldots$ & $\ldots$ & $\ldots$ & $\ldots$ & $\ldots$ & $\ldots$ & $\ldots$ \\
\hline
\end{tabular}

* Averages were based on 200 eggs at each temperature; 12 larvae and 12 pupae at $75^{\circ}$.

$\uparrow$ Specimens died before completing this period.

Larva.-For some unknown reason Crambus sperryellus proved exceedingly difficult to rear in the laboratory. At $59^{\circ} \mathrm{F}$ an entire lot of 30 larvae died in the first instar; at $75^{\circ}$ only 12 out of 200 matured successfully; at $86^{\circ} 2$ larvae out of 30 reached the seventh instar and then died; and at $98^{\circ}$ the sixth and seventh instars were attained by 1 larva each out of 30 , but these died before pupation. In these experiments, Kentucky bluegrass served as food. Various other grasses were substituted without significantly better results (table 1, p. 270). At about $75^{\circ}$ the larval period averaged 37.6 days (table 8 ), as opposed to 23.7 days for $C$. bonifatellus.

Besides appearing bulkier, the larvae were much more sluggish in all stages than Crambus bonifatellus and constructed their shelters more carefully. Ordinarily Crambus sperryellus had 7 instars, but sometimes an eighth and even a ninth.

Table 5 (p. 283) presents measurements of the cast head capsules. As may be seen by comparing the columns on actual and on theoretical breadth, the increase in head size roughly follows a geometrical progression with a factor of 1.43.

Pupa.-Specimens reared in the laboratory at about $75^{\circ} \mathrm{F}$ emerged in 10 to 13 days, with an average of 11.2 , as compared with a corresponding period of 7.7 days for Crambus bonifatellus (table 8). 


\section{SEASONAL HISTORY}

In contrast with the eastern North American species, whose seasonal histories are characterized by definite summer broods, the California lawninfesting Crambus appear to breed continuously from May through October. The explanation may be that the California species have an economic history

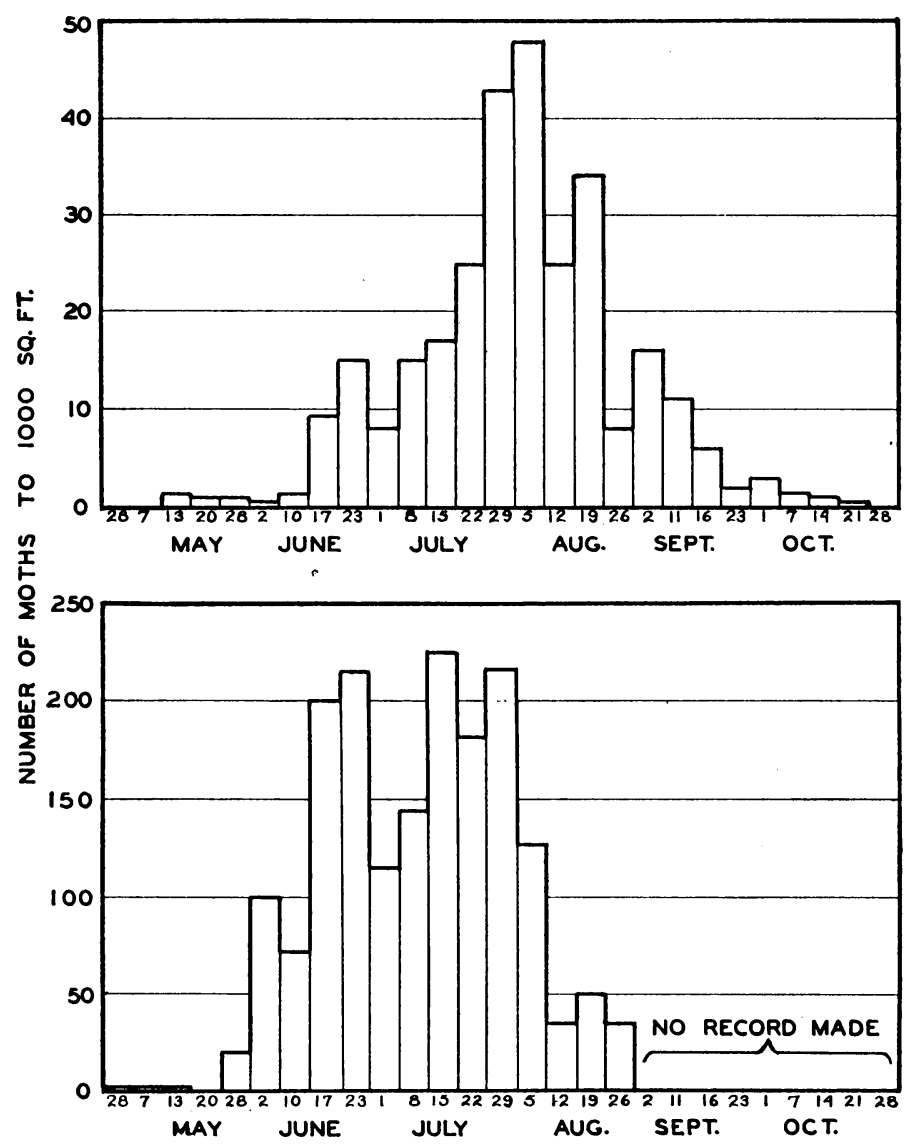

Fig. 11. - Comparison of the weekly flight record of Crambus bonifatellus over two different lawns in Los Angeles, 1941. Lower graph based on a more heavily infested lawn and drawn to a smaller scale.

only on artificially watered lawn grass, which provides a constant supply of fresh food under relatively moist conditions. The eastern species, on the other hand, which attack primarily unirrigated grassland or grain crops, depend on spring and summer rains for moisture. According to Ainslee (1930), “... a continuous growth of young, tender grass is essential to the welfare of the larvae [of $C$. teterellus Zinck.], especially while they are small, and the mortality is very great among larvae hatching when the ground is dry and hot and the grass rough and closely cropped." Ainslee states further : "Apparently 
the larvae approaching or reaching full development during such a dry period lie quiescent for some time, instead of pupating immediately, but resume their development when supplied with moisture." Infestations of well-kept turf in eastern North America have been largely incidental to those on unirrigated land, and no seasonal-history studies have been reported from turf alone.

According to field notes and collecting records made in 1939, 1940, and 1941 in the Los Angeles area, adult moths were fairly common from the middle of May to the middle of October. Early-season records for Crambus sperryellus were April 20, 1939 ; April 11, 1940; and March 26, 1941. For C. bonifatellus early records were April 28, 1939 ; April 13, 1940 ; March 26, 1941 ; and January 23,1942 (one female at light). Late-season records for C. sperryellus were October 15, 1938; October 22, 1939 ; October 19, 1940; and October 21, 1941. For C. bonifatellus late records were October 15, 1938; November 1, 1939 ; October 19, 1940; and November 17, 1941. The early records were of females, and all the late ones of males. The following are early- and late-season flight records from sections outside the Los Angeles area.

Crambus sperryellus: San Diego, October 27, 1913 (W. S. Wright) ; San Diego, April 3, 1941 (R. M. Bohart) ; Potholes, Imperial County, April 7, 1923 (E. P. Van Duzee) ; Whittier, March 17, 1940 (R. H. Smith) ; Sacramento, November 20, 1928 (H. H. Keifer) ; Mill Valley, Marin County, October 24, 1926 (E. P. Van Duzee).

Crambus bonifatellus: San Diego, March 4, 1916 (W. S. Wright), April 3, 1941 (R. M. Bohart) ; Riverside, March 8, 1941 (R. H. Smith) ; Lompoc, March 28, 1941 (R. M. Bohart) ; San Franciseo, April and October (R. M. Bohart); Berkeley, October (R. M. Bohart).

During the 1941 season, Crambus bonifatellus moth flight was observed regularly on two lawns in West Los Angeles. These data are presented graphically in figure 11. On one lawn the first moth was seen May 13, and the last specimen on October 21; but most of the flight occurred during 3 months between June 17 and September 16. Heaviest flights observed were about the middle of this period, on July 29 and August 5. On the second lawn the first flight noted was on April 28, and most of the flights came between June 2 and August 26. No single peak was noted on the second lawn. Records of 200 or more moths to 1,000 square feet were made on June 17, June 23, July 15, and July 29.

On the basis of field observations, particularly on the reinfestation of treated lawns, and laboratory rearing data (tables 6 and 8, pages 285 and 287), it seems that in the Los Angeles area Crambus bonifatellus completes four generations a year and C. sperryellus only three. Apparently, however, the generations overlap in both species.

The California lawn moths seem to overwinter in the larval stage only. This agrees with published findings on other species of Crambus in eastern North America. In California the writer brought sixth-instar larvae of $C$. bonifatellus and C. sperryellus to the surface of lawns with pyrethrum solution in November, December, January, February, and March of 1940 and 1941. Specimens dissected from sod during the winter were found in tubelike shelters resembling those where pupation takes place and somewhat more tightly constructed than larval shelters made during the summer. The overwintering shelters probably serve as protection against natural enemies as well as against climatic conditions. In the opinion of Ainslee (1923a), similar shelters of 
Crambus mutabilis may be used primarily to keep the larvae dry, not to protect them from cold.

The size of the overwintering population probably varies greatly, depending on the activity of natural enemies and upon the climate. Pyrethrum tests

TA,BLE 9

Parasites Recorded From North American Species of Crambus

\begin{tabular}{|c|c|c|c|}
\hline Parasite & Host species of Crambus & Locality & Reference \\
\hline \multicolumn{4}{|c|}{ Ichneumonidae } \\
\hline 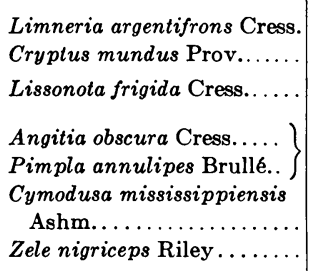 & 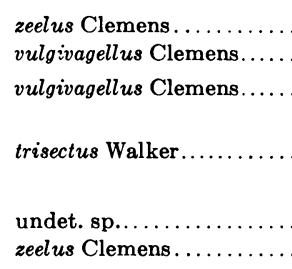 & 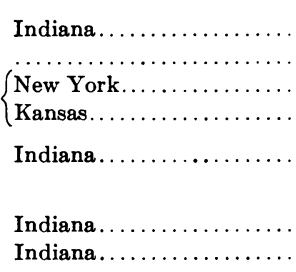 & $\begin{array}{l}\text { Anon. (1890) } \\
\text { Anon. (1890) } \\
\text { Anon. (1891) } \\
\text { Miller (1940) } \\
\text { Ainslee (1927) } \\
\text { Ainslee (1927) } \\
\text { Anon. (1890) }\end{array}$ \\
\hline \multicolumn{4}{|c|}{ Braconidae } \\
\hline 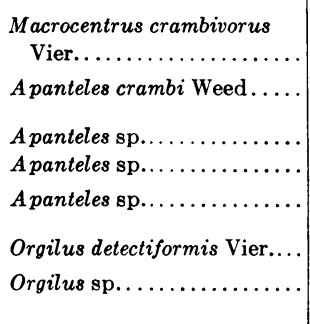 & 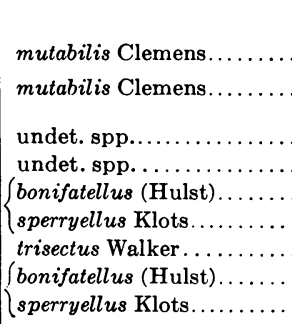 & 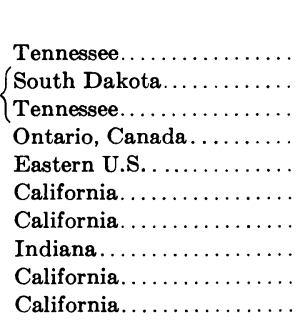 & $\begin{array}{l}\text { Ainslee }(1923 a) \\
\text { Ainslee }(1923 a) \\
\text { Ainslee }(1923 a) \\
\text { Stirret and Arnott (1932) } \\
\text { Noble (1932) } \\
\text { Original records } \\
\text { Original records } \\
\text { Ainslee (1927) } \\
\text { Original records } \\
\text { Original records }\end{array}$ \\
\hline \multicolumn{4}{|c|}{ Tachinidae } \\
\hline $\begin{array}{l}\text { Phorocera claripennis Macq. } \\
\text { Exorista nigripalpis Towns.. } \\
\text { Zenillia caesar Aldrich...... } \\
\text { Aplomyia confusionis Sllrs.. }\end{array}$ & 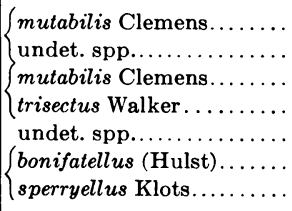 & 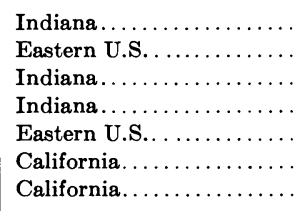 & $\begin{array}{l}\text { Ainslee (1927) } \\
\text { Noble (1932) } \\
\text { Ainslee (1927) } \\
\text { Ainslee (1927) } \\
\text { Noble (1932) } \\
\text { Original records } \\
\text { Original records }\end{array}$ \\
\hline \multicolumn{4}{|c|}{ Fungi } \\
\hline $\begin{array}{l}\text { Isaria } \mathrm{sp} . \ldots \ldots \ldots \ldots \ldots \ldots \\
\text { Empusa } \text { sp.................. } \\
\text { Beauveria bassiana (Bak.)... }\end{array}$ & 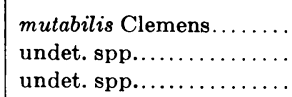 & $\begin{array}{l}\text { Tennessee } \ldots \ldots \ldots \ldots \ldots \ldots \\
\text { Ontario, Canada } \ldots \ldots \ldots \ldots \\
\text { Indiana } \ldots \ldots \ldots \ldots \ldots \ldots\end{array}$ & $\begin{array}{l}\text { Ainslee (1923a) } \\
\text { Stirret and Arnott (1932) } \\
\text { Noble (1932) }\end{array}$ \\
\hline
\end{tabular}

were made February 3, 1942, on a lawn that had been the subject of flight records the previous summer (fig. 11, upper graph). Twenty plots, 10 square feet in area, were selected at random over 3,000 square feet. Six of these plots harbored 1 mature Crambus bonifatellus larva each. From this test it was estimated that 30 larvae were present to 1,000 square feet, as compared with the average of 150 larvae estimated for the same area on August 1, 1941. 


\section{NATURAL ENEMIES}

Lawn moths have numerous natural enemies, whose abundance varies from year to year and whose value in control is difficult to estimate. Although many species appear to be casual predators, a few almost always accompany lawn moths and may assist in limiting their activities and in checking the reinfestation of treated lawns.

\section{PARASITES}

So far as can be determined, 15 species of insect parasites and 3 species of fungi have been recorded in the literature as preying upon North American species of Crambus. This information is summarized in table 9. Three species of parasites have been reared by the writer from California species. All these are in genera reported as parasites on eastern sod webworms.

Orgilus.-Parasites reared from pupal shelters of Crambus bonifatellus and C. sperryellus in Los Angeles, and collected by sweeping over turf there and in Redding and Bakersfield, were identified by C. F. W. Muesebeck as belonging to a new species of braconid of the genus Orgilus (figs. 12 and 13, C and $D$ ). The species was observed in large numbers flying over Los Angeles lawns in August and September, 1941. Of the $C$.bonifatellus pupae taken from one such lawn on August 8, 1941, 40 per cent had been parasitized by Orgilus. Known stages of the species concerned may be briefly described as follows :

Female: black with red legs, labrum and

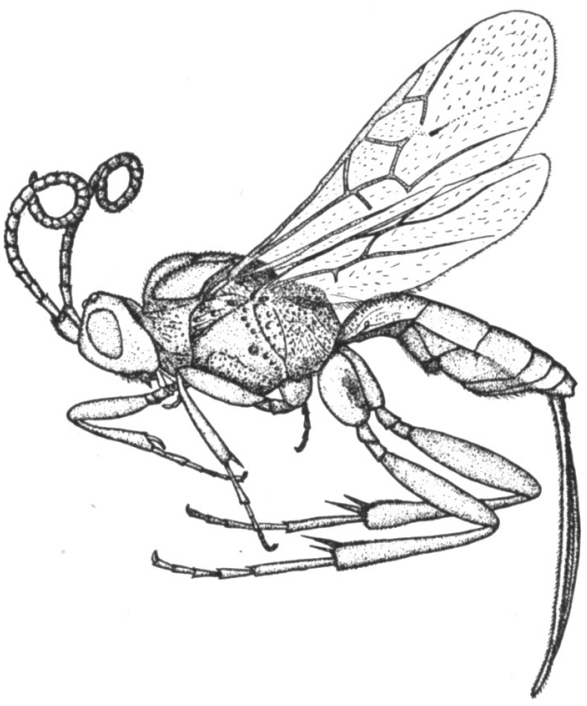

Fig. 12.-Orgilus sp., a larval parasite of crambus bonifatellus and $C$. sperryellus. mandibles partly reddish, abdomen red and black, with the red sometimes restricted mainly to the second tergite; wings dusky, stigma dark brown; length of body (excluding antennae and ovipositor) $3.5 \mathrm{~mm}$; length of antenna about $2.7 \mathrm{~mm}$; length of ovipositor measured from tip of abdomen $2.5 \mathrm{~mm}$. Male: markings as in female; length of body (excluding antennae) $3.5 \mathrm{~mm}$; length of antenna $4.0 \mathrm{~mm}$. Cocoon formed within the pupal shelter of the host; oval, golden brown, translucent, parchmentlike, covered thinly with silk fuzz; length $4.5 \mathrm{~mm}$; greatest diameter $2.0 \mathrm{~mm}$.

Apanteles.-Specimens of parasites reared from prepupal larvae of Crambus bonifatellus and $C$. sperryellus infesting a Los Angeles lawn were determined by C. F. W. Muesebeck as a new species of Apanteles (fig. 13, A). This wasp appears common throughout the Los Angeles area, having been collected for several years on lawns in Inglewood, Southgate, San Gabriel, Pasadena, Hollywood, Van Nuys, West Los Angeles, and Culver City. The known stages are briefly described as follows :

Female: black with yellowish-red legs, which are darkened at the apices of the femora and tibiae; wings nearly transparent; the veins and stigma pale brownish. Length of body 
(excluding antennae and ovipositor) $2.0 \mathrm{~mm}$; length of antenna $1.7 \mathrm{~mm}$; ovipositor extruding about $0.6 \mathrm{~mm}$ beyond end of body. Male: coloration about as in female except that the first 4 abdominal sternites are yellowish red. Length of body (excluding antennae) $2.0 \mathrm{~mm}$; length of antenna $2.0 \mathrm{~mm}$. Cocoon: oval, tightly woven of glistening white silk with stray threads scattered over the surface; opening by a circular hinged cap at the anterior end. Length $3.0 \mathrm{~mm}$; diameter about $1.2 \mathrm{~mm}$.

Aplomyia.-A species of tachinid fly reared from larvae of Crambus bonifatellus and C. sperryellus collected in Riverside and in Los Angeles was iden-
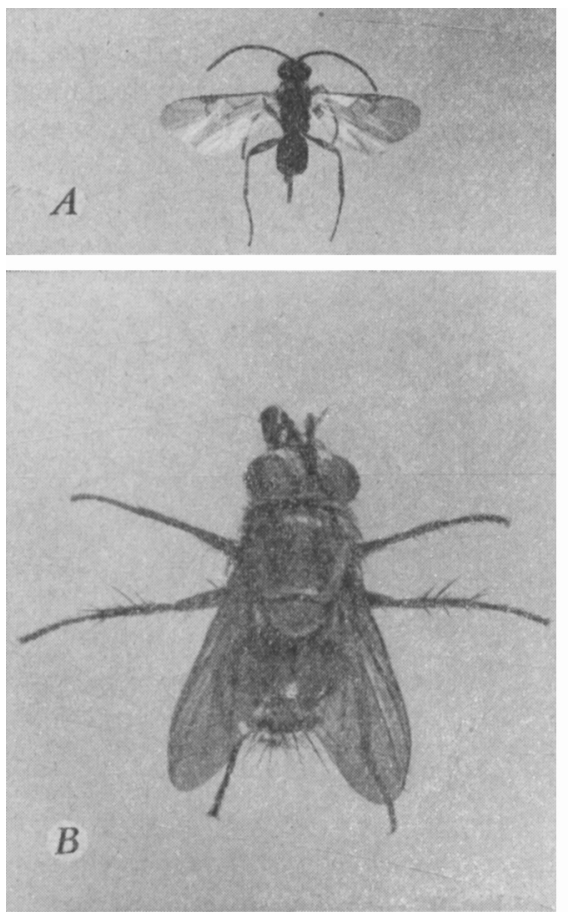

Fig. 13.-Parasites of Crambus spp. in California lawns: A, Apanteles sp.; $B$, Aplomyia confusionis Sllrs.; C. Orgilus sp.; D, pupal cocoon of Crambus bonifatellus containing cocoon of Orgilus sp.

tified by H. J. Reinhard as Aplomyia confusionis Sllrs. (fig. 13, B). The adults were commonly collected by sweeping infested lawns in Riverside and Los Angeles. The known stages are briefly described as follows :

Female: black, with a silvery pollinose covering that is especially prominent on the face and at the bases of the second and fourth abdominal tergites; compound eyes brick red in life; dorsum of thorax with 5 poorly defined, broad, pollinose stripes. Length of body 6.0 $\mathrm{mm}$; breadth of abdomen $2.2 \mathrm{~mm}$. Puparium, formed after emergence from the host pupa: broadly oval, pale brownish red. Length $5.0 \mathrm{~mm}$; greatest breadth $2.5 \mathrm{~mm}$.

\section{DISEASES}

A few records have been published of fungus diseases and undetermined bacterial and virus diseases that attack eastern species of Crambus. At certain times, notably in late fall, the writer has witnessed sudden decreases in sod- 
webworm population that apparently could not be attributed to the weather, to predators, or to insect parasites. Larval diseases may occasionally have been responsible. In the laboratory, larvae reared at $75^{\circ}$ and $86^{\circ} \mathrm{F}$ often sickened in the fourth and following instars and died after a paralysis lasting a day or two. The body contents then rapidly decomposed into a dark-brown liquid. Both species of lawn moths were affected, especially $C$. sperryellus. Dead and nearly dead larvae bore no evidence of fungus. Four species of bacteria were isolated from sick larvae by A. J. Salle. ${ }^{\circ}$ These were a small Gram-negative rod (probably Escherichia coli), a·short and fat Gram-negative rod, a species of Staphylococcus, and a species of Streptococcus. Broth cultures of these four bacteria were poured over grass, which was then fed to Crambus larvae; but no increase in mortality took place as compared with larvae fed upon untreated grass.

\section{PREDATORS}

Birds.-Despite their beneficial activities as predators on insect larvae in the grass, birds are sometimes a nuisance on the putting greens of golf courses, where they tear up the turf in search of food. Most greenkeepers believe, however, that the benefit derived from the birds offsets this damage.

$\mathrm{By}$ far the most common insectivorous bird on California lawns is the Brewer blackbird, Euphagus cyanocephalus Wagl." The writer has frequently seen many hundreds of these in a single flock searching systematically over a lawn for insects. Several times it was possible to approach closely enough to identify their prey, which was chiefly sod webworms, cutworms, skipper larvae, and angleworms. Other birds observed feeding on lepidopter-
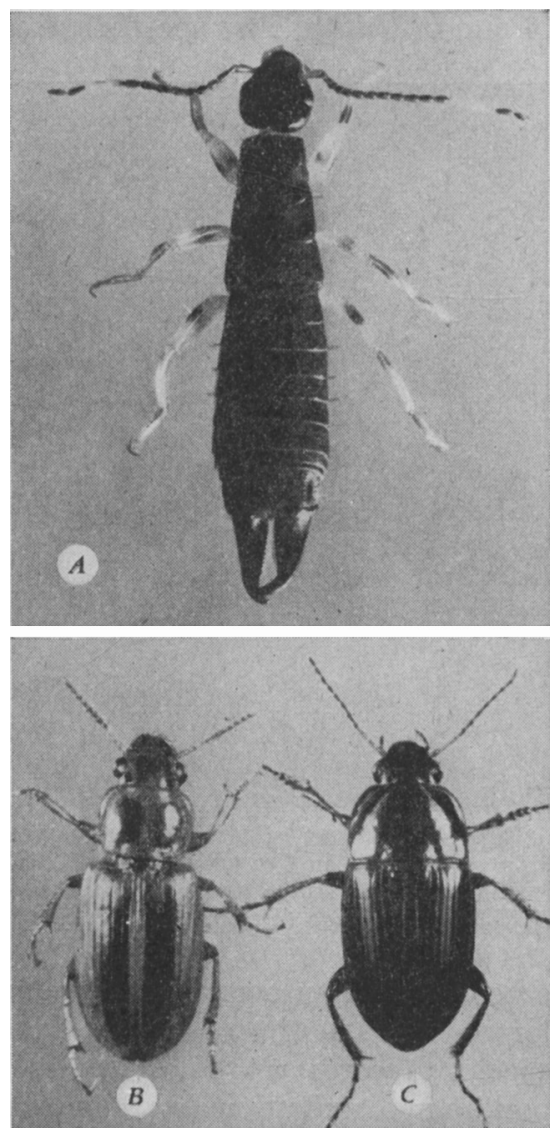

Fig. 14.-Predators on Crambus spp. in California lawns: $A$, the ring-legged earwig, Euborellia annulipes (Lucas); $B$, Agonoderus lineola Fab.; C, Celia californica (Dej.). ous larvae in lawns are the meadow lark, Sturnella neglecta (Aud.) ; the killdeer plover, Aegialitis vocifera (Linn.); the western mockingbird, Mimus polyglottos leucopterus (Vigors) ; the robin, Turdus migratorius Linn.; and the shrikes, Lanius spp.

\footnotetext{
${ }^{6}$ Professor of Bacteriology, University of California at Los Angeles.

${ }^{7}$ Determinations of birds in this paragraph by Loye H. Miller, Professor of Biology, Emeritus, University of California at Los Angeles.
} 
Vespid Wasps.-The common yellowjacket, Vespula pennsylvanica (Saussure), is a robust black and yellow wasp with a short, stout abdomen. The workers average about $11 \mathrm{~mm}$ in length. They are occasionally seen about lawns, and in one instance large numbers were observed carrying off sodwebworm larvae from a severe infestation.

Polistes spp. are moderately elongate wasps, with an abdomen that tapers toward the base but has no long, narrow petiole. The workers average about $16 \mathrm{~mm}$ in length. Two species are common in California, $P$. fuscatus aurifer

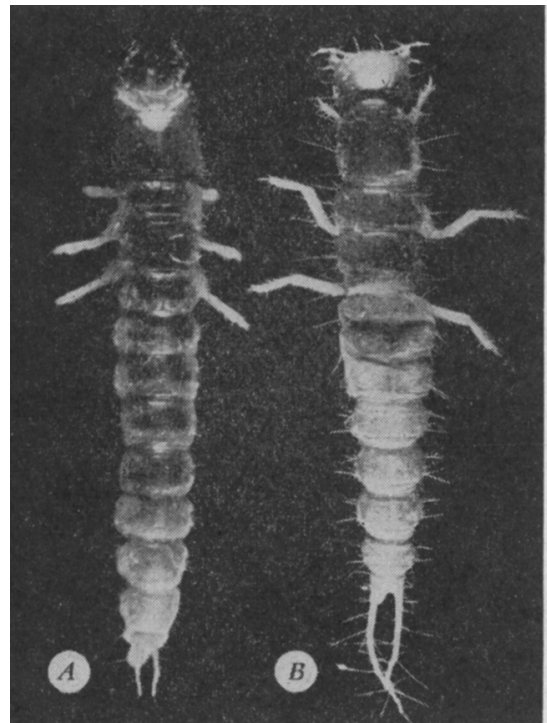

Fig. 15.-I - Larvae of two common carabids predaceous on Crambus spp. in California lawns: $A$, Agonoderus lineola Fab.; $B$, Celia californica (Dej.). Saussure, and $P$. anaheimensis Provancher. The former is black and yellow; the latter chiefly red and yellow. Wasps of both species have been observed several times while carrying off lawn-moth larvae.

The Ring-legged Earwig.-Euborellia annulipes (Lucas) is a common lawn inhabitant in southern California (fig. 14, A). It is a wingless species, about $15 \mathrm{~mm}$ long at maturity, reddish brown, the antenna subapically annulated with whitish, and the yellowish leg spotted with brown. The stout forceps can close tightly along the entire inner surface. This species is probably an important insect predator on lawninfesting caterpillars. In laboratory tests, larvae of Crambus bonifatellus were quickly seized and crushed between the powerful forceps of the earwigs. If a larva continued to struggle, the earwig gripped it at one end with the forceps and began feeding on the other end. In an overnight test one female earwig consumed 25 first-instar larvae of $C$. bonifatellus, and another dealt similarly with $25 \mathrm{eggs}$ of the species. According to Klostermeyer (1942), the ring-legged earwig is cosmopolitan in distribution and though omnivorous, prefers an insect diet.

Predaceous Ground Beetles.-Two carabids, Celia californica (Dej.) and Agonoderus lineola Fab. (fig. 14, $C$ and $B$ ), are frequent lawn inhabitants in southern California. The former is a glossy black beetle 12 to $13 \mathrm{~mm}$ long, the antennae reddish basally, the tibiae and tarsi brownish, and the elytra with fine longitudinal striae. The mature larva is about $20 \mathrm{~mm}$ long, including the bristly caudal processes, which measure about $4.5 \mathrm{~mm}$ (fig. 15, B). The larval head and pronotum are reddish brown, the mesonotum, metanotum, and legs brownish yellow; the abdomen is gray. The mandibles are slender and untoothed.

The adult of Agonoderus lineola is 10 to $13 \mathrm{~mm}$ long and is brownish yellow, marked with brown or black. Two indistinctly margined longitudinal brown lines on each elytron are characteristic. The mature larva is about $20 \mathrm{~mm}$ long, 
including the bristly caudal processes, which measure $2 \mathrm{~mm}$ (fig. 15, $A$ ). The larval head and thorax are brownish yellow, and the abdomen is gray. The stout mandibles have a large tooth on the inner surface.

According to laboratory tests, adults and larvae of both these species of carabids feed readily on larvae and eggs of sod webworms. Considering their abundance, these beetles may often be important predators on Crambus in lawns.

Rove Beetles.-Numerous species of staphylinids live in lawns. Many of these are potential predators on sod webworms.

\section{CONTROL OF LAWN MOTHS}

Control studies were carried out by the writer from August, 1938, to October, 1942. Since that time a number of new materials, such as DDT, have been introduced and it appears likely that they will have a place in lawn-insect control. As the new insecticides have not yet been evaluated, only a summary of results is presented now.

As reported in the literature (Bohart, 1940 ; Houser, 1931; Hutson, 1933; Jewett, 1939; North and Thompson, 1933; Price, 1931; Stone and Elmore, 1937), materials most widely used for sod-webworm control were pyrethrum compounds, lead arsenate, and dichloroethyl ether.

Materials tested by the writer were pyrethrum compounds, rotenone compounds, ground tobacco, nicotized powder, cuprous cyanide, dichloroethyl ether, cryolite, and various arsenical compounds. When used in practical quantities, all of these except the ground tobacco and nicotized powder killed a high percentage of larvae present in the grass at the time of application. In some years, however, particularly with an early summer, reinfestation of lawns treated with pyrethrum compounds, rotenone compounds, and dichloroethyl ether was a serious problem, 3 or more applications being required to keep the grass in good condition. The remaining materials had a more lasting effect, but cuprous cyanide was not generally available and was expensive, and cryolite had an unfavorable reaction on the grass.

Arsenicals used were acid and basic lead arsenate, and calcium arsenate. Of these the acid lead arsenate gave best results. One application was generally sufficient to control lawn moths for the season; occasionally a second treatment was necessary.

Acid lead arsenate is better used as a spray than as a dust because of the greater adhesion and more even distribution. If the lawn is not too large, the application can be made with a sprinkling can. Experience has shown that 1 man can spray 1,000 square feet in about an hour. A thorough mixture can be obtained by placing a measured amount of lead arsenate in the bottom of a sprinkling can and filling the can with a strong spray of water from a hose nozzle. The dosage found most satisfactory was 5 pounds of lead arsenate to 50 gallons of water applied to 1,000 square feet of sod. With most brands of lead arsenate this is equivalent to $1 \frac{1}{4}$ standard measuring cups of insecticide (4.8 ounces) to 3 gallons of water applied to 60 square feet. For convenience, 10foot and 6-foot sticks can be used to mark off unit areas of the lawn as the treatment progresses. 


\section{DISEASES AND MINOR PESTS OF CALIFORNIA LAWNS}

Many pests and fungus diseases are encountered in lawns. These may act separately or together in damaging the grass; in the latter case, diagnosis is often difficult. The following are notes on certain common pests and diseases observed by the writer in California.

Skippers.-The fiery skipper, Hylephila phylaeus Drury (Hesperiidae), is a common lawn inhabitant in California. According to Comstock (1927) it is "an exceedingly abundant butterfly throughout the lowlands of southern California. Its range extends northward to the San Francisco Bay district, southward to Argentina and east to the Atlantic coast." The writer has collected the species in many parts of California.

Despite its widespread abundance, it is only occasionally reported as injuring lawns. Five such instances have been observed, one each in Redding, Riverside, and Montebello, and two in Los Angeles. The lawn involved was always of bent grass. In the early stages the infestations were marked by isolated round spots, 1 to 2 inches in diameter, produced by the feeding of individual larvae. In two of the lawns observed, the spots had coalesced, and most of the lawn was killed. Although injury to bent grass appears to be most severe, larvae will feed on all the common lawn grasses.

In the laboratory, specimens were reared at about $75^{\circ} \mathrm{F}$ on Bermuda grass in an average of 48 days from egg to adult. The hemispherical eggs are glued singly to grass blades (fig. 16, $D$ ) as the female lights on the lawn during the heat of the day. The egg has an average breadth of $0.70 \mathrm{~mm}$. The larva is about $25 \mathrm{~mm}$ long and has a unique, strongly constricted neck (fig. 16, $C$ ). The black head is mottled or striped with brown, and has a granular surface. The body is brownish yellow, sometimes with indistinct longitudinal stripes. The pronotal shield is a narrow transverse black band, and the caudal plate a mottled brown. The pupa, 15 to $18 \mathrm{~mm}$ long, is rather thickly covered with bristly hairs. It is yellowish brown, with a conspicuous black dorsal line that is broken toward the end of the abdomen, and with two prominent black dashes on the thorax parallel to the median line. The pupa is found free in the grass-root zone near the surface. The adult has a wingspread of 23 to $30 \mathrm{~mm}$. The male has orange-yellow wings spotted with black, whereas the female is dark brown with orange-yellow spots (fig. 16, $A$ ).

Conspicuous white cottony masses in the lawn indicate the presence of skippers. These masses are the pupal cocoons of a braconid, Apanteles sp. (determined by C. F. Muesebeck). This parasite (fig. 16, B) attacks the larvae of Hylephila phylaeus and may constitute an effective check on the species. Another parasite, Amblyteles n. sp. (determined by R. A. Cushman), has been reared from pupae of the fiery skipper collected in Santa Rosa, Los Angeles, Montebello, and Riverside.

From observations made on lawns treated for sod webworms, Hylephila phylaeus larvae appear somewhat less susceptible to pyrethrum, dichloroethyl ether, and acid lead arsenate sprays than the Crambus species. In two tests supervised by the writer, rather satisfactory control on heavily infested bent- 

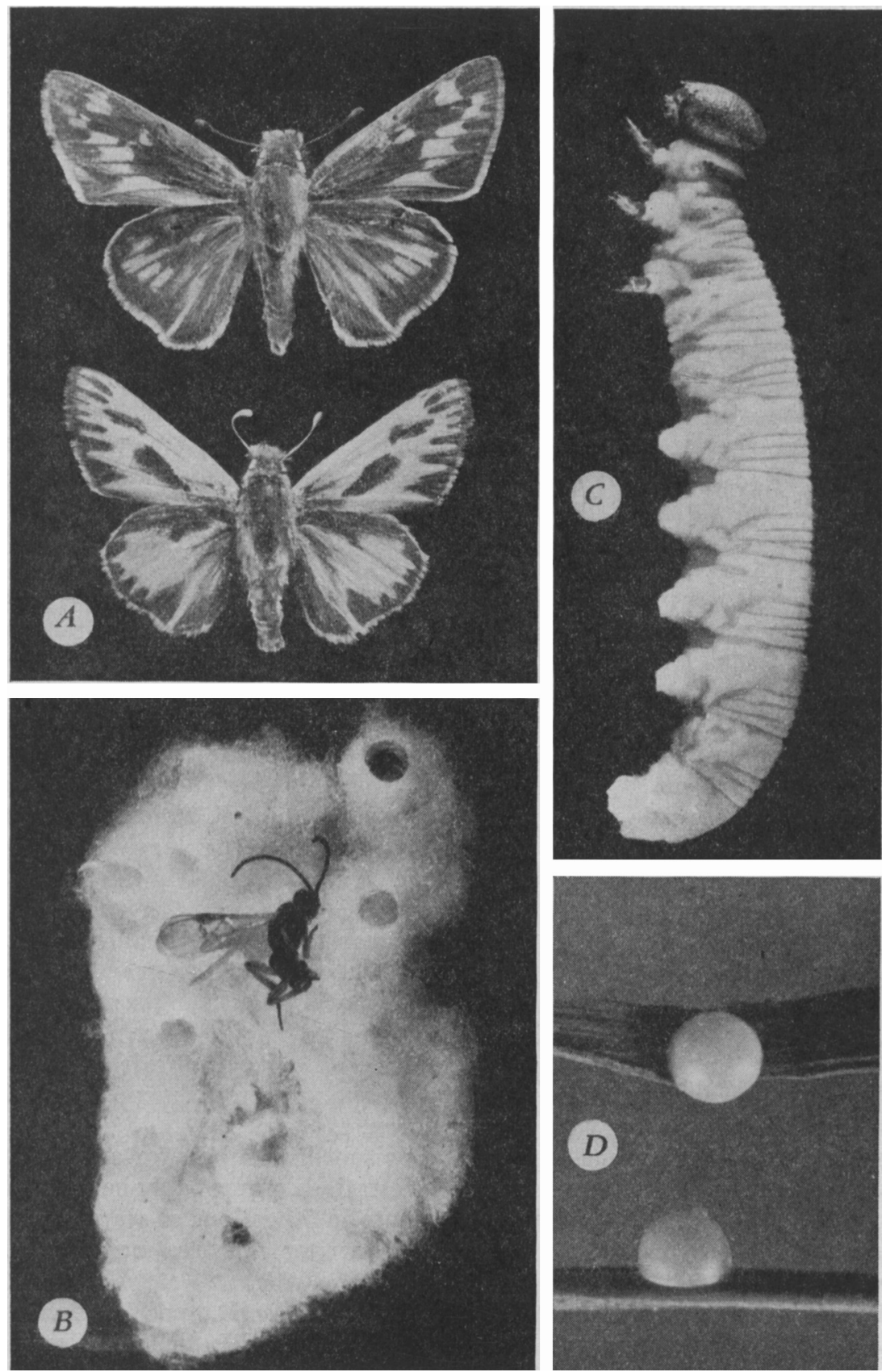

Fig. 16.-The fiery skipper, Hylephila phylaeus Drury, and its principal parasite: $A$, adult female (upper) and male (lower) of $H$. phylaeus; $C$, the mature larva; $D$, eggs in natural position on grass blades (greatly magnified); $B$, adult and cocoon mass of A panteles sp. near A. hesperidivorus Vier., reared from a fiery skipper larva. 
grass lawns followed an application of acid lead arsenate spray, 5 pounds in 50 gallons of water to 1,000 square feet. For best results, probably, the lead arsenate should be increased to 10 pounds.

Cutworms.-Three species of cutworms are commonly found in lawns (fig. 17). Occasionally they may cause severe injury, particularly to bent grass. In the lawn their presence is usually indicated by small spots, 1 or 2 inches in diameter. Close examination of such a spot should reveal definite evidence of feeding, with the grass chewed below the mowing level, and with a hole about the thickness of a lead pencil leading to the grass roots where the cutworm is lodged.

The armyworm, Cirphis unipuncta (Haw.), is about $40 \mathrm{~mm}$ long at larval maturity. The head is yellow, mottled with brown; and the dark-gray body is ornamented with 5 longitudinal yellow stripes, 3 on the dorsum and 1 on each side. The pupa is about $15 \mathrm{~mm}$ long and dark reddish brown. The adult has a wingspread of 37 to $42 \mathrm{~mm}$ (fig. 17, $A$ ). The forewing is tan, with a small silvery eyespot that subtends an oblique dark line reaching the tip of the wing. The hind wings are light on the basal half, dark on the apical half, and have dark venation. In the laboratory, specimens reared at $75^{\circ} \mathrm{F}$ on bluegrass took an average of 48 days from egg to adult.

The granulate cutworm, Feltia subterranea (Fab.), is about $35 \mathrm{~mm}$ long at larval maturity. The head is mainly dark brown, but variegated with lighter brown. The body, dark gray mottled with black, presents a granulated appearance. The adult's wingspread is 28 to $38 \mathrm{~mm}$ (fig. 17, $C$ ). The forewing has a light tan ground color and black markings. Two pale eyelike marks separated by a black bar appear in the upper middle of the wing, and a large subapical black spot is present along the anterior wing margin. The hind wings are silvery white, with pale venation. A single specimen of $F$. annexa was reared to maturity at about $75^{\circ} \mathrm{F}$ on bluegrass cuttings. The egg, larval, and pupal stages took 5, 24, and 9 days, respectively, or a total from egg to adult of 38 days.

The variegated cutworm, Peridroma margaritosa (Haw.), is about $45 \mathrm{~mm}$ long at larval maturity. It is gray or brown with blotchy gray and black lateral markings, and with a median dorsal row of pale, small, somewhat diamond-shaped spots. The adult has a wingspread of 37 to $47 \mathrm{~mm}$ (fig. 17, B). The forewing is a mottled dark gray or brownish gray, often with a purplish tint. In the upper middle of the wing are two indistinct eyelike spots. The hind wings are whitish to gray, with dark venation.

According to commercial operators, a poisoned bran bait for cutworms in lawns has not proved satisfactory. An infestation can probably be controlled by applying 10 pounds of acid lead arsenate in 50 gallons of water to 1,000 square feet. In two instances observed by the writer, this treatment appeared successful.

Pyralids.-The lucerne moth, Nomophila noctuella (D. and S.) (fig. 17, D, and fig. 18), occurs in lawns throughout California. As the common name implies, it is primarily a pest of alfalfa. It likes other legumes, including white clover, but in their absence will feed on grass. In laboratory rearings the larvae were fed various lawn constituents; they seemed definitely to prefer white clover to bluegrass, orchard grass, or Bermuda grass. Specimens reared on 
white clover at about $75^{\circ} \mathrm{F}$ took an average of 32 days from egg to adult. In Illinois, according to Flint (1922), the species damages red clover, sweet clover, and alfalfa, but also feeds upon corn, purslane, bluegrass, white clover, mustard, cinquefoil, foxtail, and soybean.

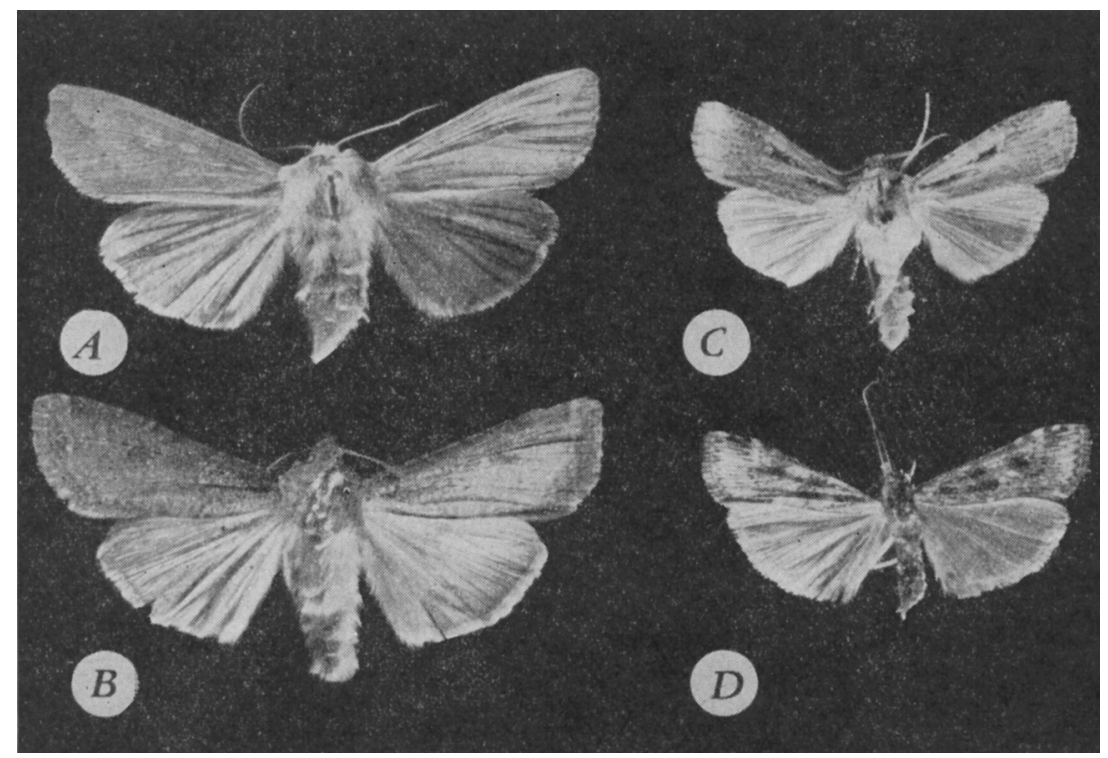

Fig. 17.-Common lawn-infesting moths: $A$, the armyworm, Cirplius unipuncta (Haw.); $B$, the variegated cutworm, Peridroma margaritosa (Haw.); $C$, the granulate cutworm, Feltia subterranea (F.); $D$, the lucerne moth, Nomophila noctuella (D. and S.).

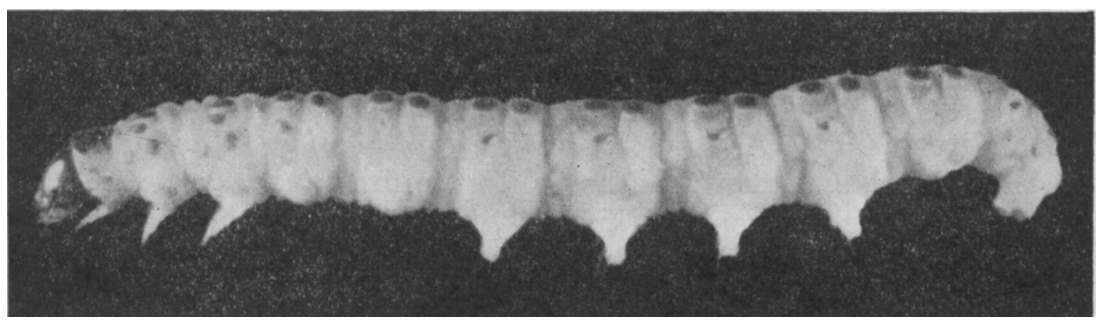

Fig. 18.-Mature larva of the lucerne moth, Nomophila noctuella (D. and S.).

Adult females collected at lights deposited clumps or rows of 5 to 50 eggs at a time on the host plants. The mature larva is slender, very active, and about $25 \mathrm{~mm}$ long, with a black or dark-brown head. The dorsum of the body is ornamented with conspicuous subspherical dark spots; these distinguish the larva from Crambus bonifatellus, in which the spots are much less uniformly shaped. The pale-brown pupa is formed within a translucent silken cocoon in the ground. The adult has a wingspread of 25 to $30 \mathrm{~mm}$; and its forewing is a mottled gray brown, with two pairs of indistinct dark spots. The hind wings are gray with dark venation. 
In the writer's experience, Nomophila noctuella has never been more than a contributing nuisance in unhealthy lawns. Apparently it is well controlled by the arsenate spray recommended for sod webworms.

Ommatopteryx texana Rob. has been seen about lawns in southern California from Bakersfield to San Diego. Adults collected at lights laid numerous nearly oval eggs on grass blades with which they were caged. The eggs were loosely attached and were easily dislodged by disturbing the grass blades. The larvae were offered cuttings of white clover, Bermuda grass, and bluegrass, but fed only on the clover. Laboratory specimens reared at about $75^{\circ} \mathrm{F}$ averaged 57 days from egg to adult. The mature larva is about $17 \mathrm{~mm}$ long. The head is almost unicolorous brown; and the body is grayish yellow, with indistinct gray spots. The pupa is formed in a fairly opaque cocoon in the ground. The adult has a wingspread of 18 to $22 \mathrm{~mm}$. The grayish forewing has two oblique transverse yellow lines at about the middle, and a marginal row of black spots edged with gold. The hind wings are whitish to gray, with gray venation.

The California Harvester Ant.-In sandy areas of southern California the California harvester ant, P.ogonomyrmex californicus (Buckley), often makes itself a nuisance by building nests in lawns. A colony creates a bare spot by clearing away the grass around its nest. The workers can bite and sting viciously. Although calcium cyanide dust poured into the nests and covered with earth is commonly used for control, the colonies are seldom exterminated in this way and will usually reappear. The writer, in a limited number of tests, employed the following methods : (1) Calcium arsenate dust, both alone and mixed with flour, was forced into the nests under pressure. (2) Cuprous cyanide dust was forced into the nests under pressure. (3) Dichloroethyl ether in concentrated form and in a 1 to 400 dilution in water was poured into nests. (4) A pyrethrum product ${ }^{8}$ in concentrated form and in a dilution of 1 to 400 in water was poured in. Each of these treatments reduced the numbers of ants and often caused the colony to move its entrance a short distance away. Apparent extermination was achieved with the diluted dichloroethyl ether and the diluted pyrethrum product if 2 gallons or more were poured into the nest.

The California Fire Ant.-Solenopsis xyloni maniosa Wheeler is a small reddish and black ant, known as the California fire ant because of its vicious sting. Colonies occasionally occur in lawns, creating large spongy areas around their nests. The pest may seriously injure the grass by chewing on the roots and crown. An apparently effective control is described by Mallis (1938) : A mixture of 1 part carbon disulfide and 3 parts carbon tetrachloride is poured into holes made with a screwdriver in the nesting site. The holes are then covered with earth and with wet burlap sacks to confine the fumes. For satisfactory results this treatment may have to be repeated two or three times over a period of 2 weeks.

The Argentine Ant.-The common house ant or Argentine ant, Iridomyrmex humilis Mayr, is a frequent and unwelcome visitor in lawns. Usually it can be controlled by a persistent use of commercial arsenical ant sirups.

White Grubs. - The larvae of Scarabaeidae, known as white grubs, often feed upon grass roots. When well grown they are fleshy whitish grubs $1 / 2$ to 1

\footnotetext{
${ }^{8}$ Containing 2 per cent pyrethrins.
} 
inch long and partially coiled, like the letter C. Their damage to California lawns is apparently sporadic, and little injury has been reported during the past few years. The most abundant lawn-infesting species of this group in southern California is Spilosota hirta (Lec.). The adult beetle is about $15 \mathrm{~mm}$ long, mostly yellowish brown, with a reddish head, black eyes, and two indistinctly outlined longitudinal brown lines on each elytron (fig. 19, $C$ ). In Los Angeles, Riverside, and intervening cities, the beetles are attracted to lights on warm midsummer evenings. Each year there is apparently a concentrated flight of adults, lasting about 2 weeks. Before and after this period the beetles are rarely encountered. The writer observed heavy flights in West Los Angeles on July 6, 1939, July 1, 1940, and June 23, 1941. In 1941, regular weekly observations were made there from February until November. The first adult Spilosota hirta was observed on June 17, and the last one on July 1. Also in 1941, flights of beetles were seen in Riverside on June 14 and in Pasadena on June 19. During all these flights, certain characteristics were observed : (1) The beetles appear at dusk in large numbers (about 1 to the square yard at the peak) and mostly disappear in about 20 minutes. (2) They fly over the lawn in zigzag fashion at a height of 1 or 2 feet. (3) During and shortly after these flights a few beetles, representing a very small proportion of the population, are attracted to street lights.

In a severe infestation of white grubs, practically all the grass roots are severed, and the lawn can be easily rolled back to expose the larvae at work.

Control methods have been carefully worked out for eastern species of lawn-infesting white grubs and should also be successful under California conditions. Hadley (1940) made the following statements concerning the treatment of lawns and other turf areas for white grubs of the Japanese beetle :

An application of lead arsenate at the rate of 10 pounds to 1,000 square feet of turf area is recommended. This small quantity of lead arsenate must be diluted to a greater bulk so that it can be uniformly distributed over the surface. The material may be mixed with about 25 times its volume of moist sand, soil, or other suitable material, and broadcast by hand, or with a hand-operated fertilizer distributor. Immediately after lead arsenate has been applied the lawn should be well watered with a hose to wash the poison into the soil. It may be expected that a lawn treated in this manner will be immune to injury by the grubs for at least 5 years.

Billbugs.-The larvae of several species of the genus Calendra (Curculionidae) frequently occur in lawns. They are small, white, legless grubs approximating $1 / 4$ to $3 / 8$ inch in length at maturity. Van Dyke (1938) recorded $C$. minimus (Hart), C. reticulatus (Boh.); C. sequoiae V. D., C. simplex (Lec.), and C.gentilis (Lec.) from lawns in the San Francisco Bay area. Species collected in turf by the writer are C. phoeniciensis (Chittn.) (fig. 19, A), C. tarda (Fall), C. glyceriae (Chittn.), and C. sequoiae V. D. (all four from southern California). Two severe infestations of $C$. tarda in bent grass have come to the writer's attention. One, in San Gabriel, was treated with three sprays, dichloroethyl ether ( 1 part to 200 parts of water and 1 gallon to the square yard), acid lead arsenate (10 pounds in 50 gallons of water to 1,000 square feet), and calcium arsenate (10 pounds in 50 gallons of water to 1,000 square feet). According to a survey 2 weeks after treatment, dichloroethyl ether

\footnotetext{
${ }^{\circ}$ Containing 30 per cent inert ingredients, including other calcium compounds.
} 
had given an excellent kill. Many dead larvae and no live specimens were found near the grass roots. The two arsenicals, however, gave only about a 50 per cent control as compared with the check. A similar infestation involving $C$. phoeniciensis was observed on Bermuda grass at Alhambra, in September, 1942. At that time much of the lawn had been killed, and crabgrass had begun to fill in the earlier-killed patches. Both adults and larvae of the billbugs abounded in the partially green grass on the fringes of dead areas. According to the gardener, lead arsenate sprayed several weeks before had failed to give satisfactory control.

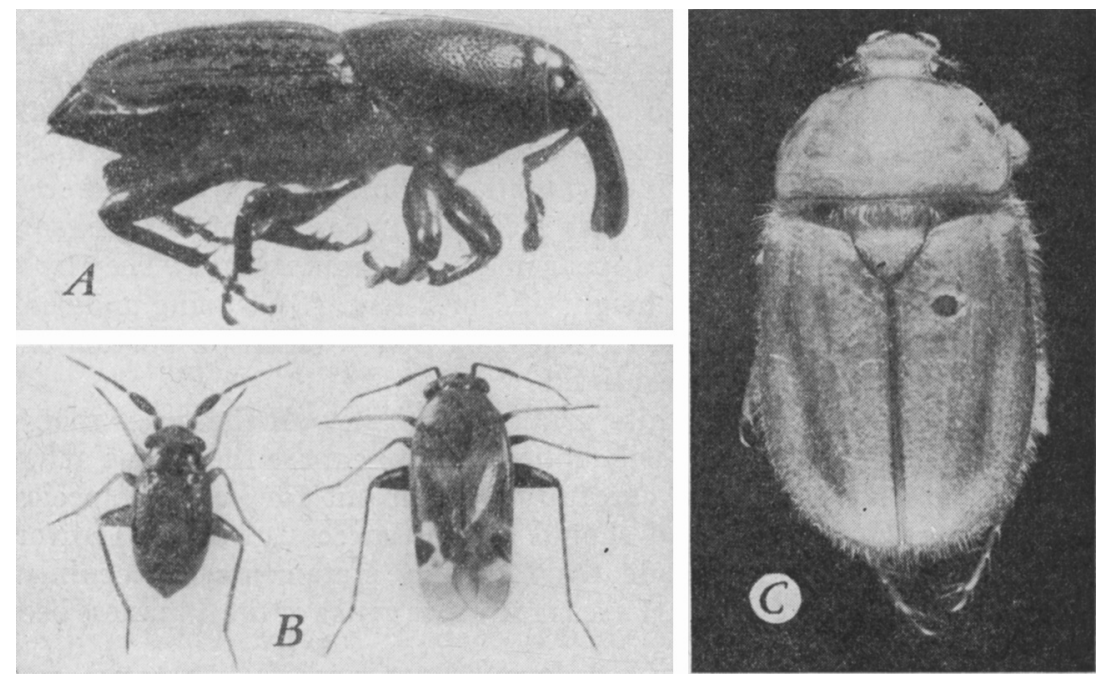

Fig. 19.-Grass-infesting insects: A, Calendra phoeniciensis (Chittn.) ; $B$, nymph and adult of Leucopoecila albofasciata Reut.; $C$, Spilosota hirta Lec.

Mirids.-A common gray and white saltatory bug found in California lawns is Leucopoecila albofasciata Reuter (fig. 19, B). If it becomes numerous, the infested lawns show retarded growth or may die out in spots. Bluegrass, Bermuda grass, and bent grass appear to be most affected. This pest is widely distributed over the United States and, according to Knight (1941), has damaged golf greens in Missouri and New York. Hamilton (1935) recommended a derris dust, a nicotine and pyrethrum dust, a nicotine sulfate and soap spray, or a pyrethrum and soap spray for controlling it on New Jersey lawns and golf courses. In a single test made by the writer, good results were obtained with a pyrethrum spray (containing 2 per cent pyrethrins) diluted 1 to 400 with water, 2 gallons being applied to 100 square feet with a 3-gallon hand-pump sprayer; also with a pyrethrum dust (0.1 per cent pyrethrins), 2 pounds to 1,000 square feet. The materials acted rapidly; most of the bugs in the treated areas were apparently dead after 10 minutes. A pronounced recovery of the grass was noted 2 weeks later.

Leafhoppers.-Many species of leafhoppers (Cicadellidae) live in lawns. Ordinarily the effect of their feeding is not noticeable if the grass is well watered and regularly fertilized. In California the species most frequently 
injurious appears to be Draeculacephala mollipes (Say). Osborn (1939) gives the life history and habits of this widely distributed green and yellow leafhopper. According to reports of commercial operators, it is easily controlled with pyrethrum in either spray or dust form.

Mites.-A grass mite, Paratetranychus stickneyi McGregor, common on Bermuda grass in southern California, can be considered a potential pest. Apparently this mite thrives when the grass is in poor condition through lack of moisture.

Pillbugs and Sowbugs.-The common pillbug, Armadillidium vulgare (Latr.), and the dooryard sowbug, Porcellio laevis Koch, are frequent lawn inhabitants (fig. 20). Although these crustaceans feed principally on dead and decaying grass, they constitute a nuisance; and a lawn is often a focal point from which other plants are attacked. Their control has been discussed by Bohart and Mallis (1942). Arsenical poison baits containing bran or vegetable meals are ordinarily recommended for sowbug and pillbug control, but appear not to be satisfactory on lawns. During experiments with sod webworms, acid lead arsenate at 10 pounds to 1,000 square feet and calcium arsenate $^{10}$ at 3 pounds to 1,000 square feet killed a high percentage of pillbugs.

Fungus Diseases.-Eleven major lawn diseases have been discussed by Monteith and Dahl (1932): brown

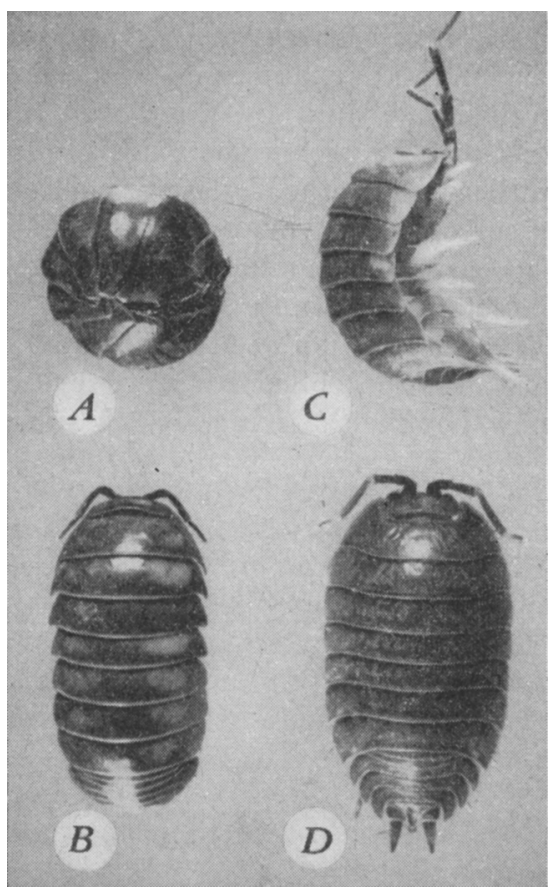

Fig. 20.-A, $B$, The common pillbug, Armadillidium vulgare (Latr.); $C, D$, the dooryard sowbug, Porcellio laevis Koch. patch (Rhizoctonia solani), dollarspot (Rhizoctonia sp.), spotblight (Pythium butleri), snowmold (Fusarium nivali), damping-off (various fungi), leafspot (Helminthosporium vagans), zonate eyespot (Helminthosporium giganteum), fairy ring (various fungi), smut (Ustilago striaeformis), rust (Puccinia spp.), mildew (Erysiphe graminis). Of these, by far the most common in California, and the most apt to be confused with lawn-moth damage, are brown patch and dollarspot.

According to the authors just cited, brown patch occurs in more or less circular spots, varying from 1 inch to 3 feet or more in diameter. The grass in the center of the affected area turns first dark and then, gradually, a light brown. On the outer borders there is usually a dark ring of more recently affected grass, which indicates that the fungus is still actively spreading. In light attacks not all the grass blades are killed, and the spot may retain a light greenish color. The disease affects various lawn constituents, including bent

\footnotetext{
${ }^{10}$ Containing 30 per cent inert ingredients, including other calcium compounds.
} 
grass, Kentucky bluegrass, ryegrass, Bermuda grass, and clover. Two types of bent grass, colonial and redtop, are particularly susceptible.

Dollarspot, a similar disease, usually appears in patches less than 2 inches in diameter, gives the dead grass a bleached straw color, and thrives at a somewhat lower temperature and in a more acid soil than the brown patch. Though creeping bent is most susceptible, dollarspot attacks many other lawn constituents. Colonial bent, redtop, and especially velvet bent are resistant. Both diseases are favored by excessive rainfall, heavy dews, fog, cloudy weather, high humidity, and high temperatures. One can distinguish them from sodwebworm injury by examining the individual grass blades. In fungus infections the brown spots are produced by the dead grass, whereas in caterpillar damage the blades are partially or wholly removed, and the brown color results mainly from the short stubble and from the exposed ground. In doubtful cases one should apply a pyrethrum solution to test for the presence of insects (see footnote 5, p. 270.

In the opinion of Monteith and Dahl (1932), brown patch and dollarspot are best controlled by mercury compounds. Fungicide manufacturers are now, however, offering organic sulfur substitutes. 


\section{SUMMARY}

The two chief lawn-infesting insects in California are Crambus bonifatellus (Hulst) and C. sperryellus Klots. These, the only representatives of the genus Crambus known to attack lawns in California, are easily distinguished by adult, larval, and pupal characters. In the adult, the forewings of $C$. bonifatellus are brown, variegated with buff, whitish, and black; whereas those of C. sperryellus are golden, with a longitudinal silver stripe. Young larvae of the two species are similar in appearance; but after the third molt, the head of $C$. sperryellus has much more distinct spots than that of $C$. bonifatellus. The pupa differs especially in the caudal process, which is blunt in C. bonifatellus and roundly pointed in C. sperryellus.

On the basis of the wing patterns, the adult Crambus bonifatellus is called the fawn-colored lawn moth whereas $C$. sperryellus is designated as the silverbarred lawn moth.

Many species of the genus Crambus in various parts of the world have been recorded as injuring agricultural crops, especially those of the grass family. Their importance as pests of lawns and golf courses in North America was not generally realized until the widespread drought of 1929 to 1932. The first report of injury to lawn grass in California was published in 1929, and since then these larvae (sod webworms) have taken a large yearly toll.

Crambus bonifatellus occurs throughout the Canadian zone of the entire Rocky Mountain and Great Basin area. In the Northwest it has been collected in British Columbia and Oregon. In California it occurs near the sea-rarely inland. C. sperryellus is restricted mainly to California, where it is common along the coast and throughout the Sacramento and San Joaquin valleys. In southern California it ranges inland as far as the San Bernardino Mountains, Needles, and the Coachella Valley.

In the field, lawn moths apparently prefer bent and young bluegrass lawns. In laboratory feeding tests, many other grasses and clover were found to be potential host plants.

The most reliable test for sod webworms is to apply a pyrethrum-containing solution to various parts of a lawn in order to bring the larvae wriggling to the surface. Other criteria of infestation that can be used are irregular brown patches near which the grass is thin and uneven, and an abundance of parasites and predators in or hovering about the turf.

Eggs are scattered by the female moth during the oviposition flight, which begins just before dusk and lasts about an hour. A few moths are attracted to artificial lights toward the end of the oviposition period and sometimes for several hours thereafter. According to laboratory tests an average female lays 200 to 300 eggs, with exceptional individuals producing over 500. Crambus bonifatellus appears to be somewhat more fecund than $C$. sperryellus.

In the laboratory Crambus bonifatellus was reared from egg to adult in an average of 35.9 days at about $75^{\circ} \mathrm{F}$. Of this period 4.5 days were taken by the egg, 23.7 days by the larva, and 7.7 days by the pupa. At $59^{\circ}$ the average time from egg to adult was 133.7 days. Six larval instars are the rule at about $75^{\circ}$.

Crambus sperryellus was reared from egg to adult in an average of 54.8 days at about $75^{\circ} \mathrm{F}$ in the laboratory. Of this period 6.0 days were taken by 
the egg, 37.6 days by the larva, and 11.2 days by the pupa. Seven larval instars are the rule at this temperature.

The California sod webworms infesting lawns appear to breed continuously throughout the late spring, summer, and early fall. The period from late October to late April is customarily passed in a semiquiescent state by mature or nearly mature larvae. In the Los Angeles area Crambus bonifatellus apparently completes four generations a year, and $C$. sperryellus only three.

Three species of parasites have been reared from California sod webworms infesting lawns - two braconids, Orgilus sp. and Apanteles sp.; and a tachinid, Aplomyia confusionis Sllrs. Occasionally these appear to play a major part in control. The more important predators are the Brewer blackbird, vespid wasps, a native species of earwig, carabids, and rove beetles.

Several insecticides when applied in sufficient concentration gave adequate temporary control of sod-webworm infestations-namely, pyrethrum and rotenone products, dichloroethyl ether, and acid lead arsenate. Of these only the lead arsenate prevented reinfestation. The most satisfactory treatment is 5 pounds of acid lead arsenate in 50 gallons of water, applied to 1,000 square feet.

The chief pests other than sod webworms in California lawns are the fiery skipper, cutworms, the lucerne moth, the California harvester ant, the California fire ant, white grubs, billbugs, Leucopoecila albofasciata, leafhoppers, sowbugs, and pillbugs.

The chief lawn diseases in California are brown patch and dollarspot. These are sometimes confused with injury from sod webworms, but the latter is distinguished by unevenness of grass height and irregularity in the shape of the dead spots. Pyrethrum-containing solution may be used as a conclusive test for the presence of the insects.

\section{ACKNOWLEDGMENTS}

The author is grateful to the many persons who have aided him in this study. R. H. Smith, who suggested the problem in 1938, contributed advice throughout, while R. J. Pence assisted with field tests and laboratory studies. Much credit also belongs to C. F. W. Muesebeck and his associates at the U.S. National Museum; to P. C. Ting, H. H. Kiefer, and Loye Miller for identifying specimens; to A. J. Salle for bacteriological investigations; to A. Mallis for advice and help in the work with ants and pillbugs; and to S. F. Bailey for contributing specimens and observations on lawn insects. 
Ainslee, G. G.

\section{LITERATURE CITED}

1922a. Webworms injurious to cereal and forage crops and their control. U.S. Dept. Agr. Farmers' Bul. 1258:1-16.

1923a. Striped sod webworm, Crambus mutabilis Clemens. Jour. Agr. Res. 24:399-414.

1923b. Silver-striped webworm, Crambus praefectellus Zincken. Jour. Agr. Res. 24:415-26.

1927. The larger sod webworm. U.S. Dept. Agr. Tech. Bul. 31:1-17.

1930. The bluegrass webworm. U.S. Dept. Agr. Tech. Bul. 173:1-25.

Anonymous.

1890. Some of the bred parasitic Hymenoptera in the national collection. Insect Life 3:59, 154, 158, 464 .

BoHART, R. M.

1940. Studies on the biology and control of sod webworms in California. Jour. Econ. Ent. 33:886-90.

Bohart, R. M., and A. Mallis.

1942. The control of pillbugs and sowbugs. Jour. Econ. Ent. 35:654-58.

Brock, A. A.

1929. Control of moths attacking lawns. California State Dept. Agr. Mo. Bul. 18:574.

Comstock, J. A.

1927. Butterflies of California. 334 p. (See specifically p. 220.) McBride Printing Co., Los Angeles, California.

DYAR, H. G.

1904. The Lepidoptera of the Kootenai district of British Columbia. U.S. Natl. Mus. Proc. 27:920.

FELT, E. P.

1894. On certain grass-eating insects: a synopsis of the species of Crambus of the Ithaca fauna. New York (Cornell) Agr. Exp. Sta. Bul. 64:45-102.

Fernald, C. H.

1896. The Crambidae of North America. Massachusetts Agr. Col. Spec. Bul. 93 p.

Flint, W. P.

1922. Studies of the life history of Nomophila noctuella. Ent. Soc. Amer. Ann. 15:154-56.

Hadley, C. H.

1940. The Japanese beetle and its control. U.S. Dept. Agr. Farmers' Bul. 1856:1-22.

Hamilton, C. C.

1935. The control of insect pests of lawns and golf courses. New Jersey Agr. Exp. Sta. Cir. 347:1-16.

Houser, J. S.

1931. Sod webworm - a new pest. Natl. Greenkeeper 5:5-10.

HuLsT, G. D.

1887. New species of Pyralidae. Ent. Amer. 3:135.

Hutson, R.

1933. Pyrethrum solutions for determining insect infestation on golf greens. Jour. Econ. Ent. 26:1171.

JEWETT, H. H.

1939. Control of sod webworms in lawns. Kentucky Agr. Exp. Sta. Bul. 391:91-106.

KeIFer, H. H.

1931. Notes on some California Lepidoptera of economic interest. California Dept. Agr. Mo. Bul. 20:613-26.

KLOSTERMEYER, E. C.

1942. The life history and habits of the ring-legged earwig, Euborellia annulipes Lucas. Kansas Ent. Soc. Jour. 15:13-18. 
KLoTs, A. B.

1940. North American Crambus. Part I. The silvery-striped species of California. Southern California Acad. Sci. Bul. 39:53-70.

KNIGHT, H. H.

1941. The plant bugs or Miridae of Illinois. Illinois Nat. Hist. Survey Bul. 22(1):1-234.

MaLlis, A. M.

1938. The California fire ant and its control. Pan-Pacific Ent. 14:87-91.

MiLleR, H. D. O.

1940. Observations on sod webworms in Kansas. Kansas Acad. Sci. Trans. 43:267-81.

Monteith, J., JR., and A. S. DAhL.

1932. Turf diseases and their control. U.S. Golf Assoc., Green Section Bul. 12:87-186.

MoznetTe, G. F.

1921. Notes on a destructive lawn insect. Florida Grower $24(22): 13$.

NoBLE, W. B.

1932. Sod webworms and their control in lawns and golf greens. U.S. Dept. Agr. Cir. 248:1-4.

North, H. F. A., and G. A. Thompson, JR.

1933. Investigations regarding bluegrass webworms in turf. Jour. Econ. Ent. 26:1117-25.

OSBORN, HeRBERT.

1939. Meadow and pasture insects. 228 p. Educators Press, Columbus, Ohio.

StirRet, G. M., and D. A. ARnott.

1932. Observations on the outbreak of sod webworms during the season of 1931. Ent. Soc. Ontario, 62d Ann. Rept. 1931:69-75.

Stone, M. W., and J. C. Elmore.

1937. Dichloroethyl ether as a control for sod webworms in lawns. Jour. Econ. Ent.30:213.

VAN DYKe, E. C.

1938. Calendra (Sphenophorus) minimus Hart in California. Pan-Pacific Ent. 14:187. 